\title{
Abundance of fluorescent biological aerosol particles at temperatures conducive to the formation of mixed-phase and cirrus clouds
}

\author{
Cynthia H. Twohy ${ }^{1}$, Gavin R. McMeeking ${ }^{2, a}$, Paul J. DeMott ${ }^{3}$, Christina S. McCluskey ${ }^{3}$, Thomas C. J. Hill ${ }^{3}$, \\ Susannah M. Burrows ${ }^{4}$, Gourihar R. Kulkarni ${ }^{4}$, Meryem Tanarhte ${ }^{5}$, Durga N. Kafle ${ }^{6}$, and Darin W. Toohey ${ }^{7}$ \\ ${ }^{1}$ Northwest Research Associates, Redmond, WA 98052 USA \\ ${ }^{2}$ Droplet Measurement Technologies, Boulder, CO 80301 USA \\ ${ }^{3}$ Dept. of Atmospheric Science, Colorado State University, Fort Collins, CO 80523 USA \\ ${ }^{4}$ Pacific Northwest National Laboratory, Richland, WA 99354 USA \\ ${ }^{5}$ Atmospheric Chemistry Department, Max Planck Institute for Chemistry, Mainz, 55128 Germany \\ ${ }^{6}$ NASA GSFC, ADNET Systems, Greenbelt, MD 20771 USA \\ ${ }^{7}$ Dept. of Atmospheric and Oceanic Sciences, University of Colorado, Boulder, CO 80309 USA \\ ${ }^{a}$ now at: Handix Scientific, Boulder, CO 80301 USA
}

Correspondence to: Cynthia H. Twohy (twohy@nwra.com)

Received: 3 February 2016 - Published in Atmos. Chem. Phys. Discuss.: 11 February 2016

Revised: 9 June 2016 - Accepted: 13 June 2016 - Published: 8 July 2016

\begin{abstract}
Some types of biological particles are known to nucleate ice at warmer temperatures than mineral dust, with the potential to influence cloud microphysical properties and climate. However, the prevalence of these particle types above the atmospheric boundary layer is not well known. Many types of biological particles fluoresce when exposed to ultraviolet light, and the Wideband Integrated Bioaerosol Sensor takes advantage of this characteristic to perform real-time measurements of fluorescent biological aerosol particles (FBAPs). This instrument was flown on the National Center for Atmospheric Research Gulfstream $\mathrm{V}$ aircraft to measure concentrations of fluorescent biological particles from different potential sources and at various altitudes over the US western plains in early autumn. Clearair number concentrations of FBAPs between 0.8 and $12 \mu \mathrm{m}$ diameter usually decreased with height and generally were about $10-100 \mathrm{~L}^{-1}$ in the continental boundary layer but always much lower at temperatures colder than $255 \mathrm{~K}$ in the free troposphere. At intermediate temperatures where biological ice-nucleating particles may influence mixed-phase cloud formation ( $255 \mathrm{~K} \leq T \leq 270 \mathrm{~K}$ ), concentrations of fluorescent particles were the most variable and were occasionally near boundary-layer concentrations. Predicted vertical distributions of ice-nucleating particle concentrations based
\end{abstract}

on FBAP measurements in this temperature regime sometimes reached typical concentrations of primary ice in clouds but were often much lower. If convection was assumed to lift boundary-layer FBAPs without losses to the free troposphere, better agreement between predicted ice-nucleating particle concentrations and typical ice crystal concentrations was achieved. Ice-nucleating particle concentrations were also measured during one flight and showed a decrease with height, and concentrations were consistent with a relationship to FBAPs established previously at the forested surface site below. The vertical distributions of FBAPs measured on five flights were also compared with those for bacteria, fungal spores, and pollen predicted from the EMAC global chemistry-climate model for the same geographic region.

\section{Introduction}

Details of the formation of ice in clouds are poorly understood, especially considering the importance of this phase transition to cloud evolution, climate, and the cycling of water and trace constituents in Earth's atmosphere. Water droplets can remain supercooled at temperatures below 
$273 \mathrm{~K}$, and the presence of an ice-nucleating particle (INP) reduces the energy barrier required for the phase transformation from liquid to ice. Biological particles have received much interest in the community recently because certain ones tend to nucleate ice efficiently at warmer temperatures than mineral dust particles (Murray et al., 2012). While laboratory studies show mineral dust and some types of biological particles can act as INPs, there is conflicting evidence regarding the importance of biological particles as INPs in the atmosphere (Després et al., 2012). Modeling studies suggest that biological INPs are not very important globally, mainly because their concentrations at cold cloud levels are thought to be relatively low compared to other INPs like mineral dust (Hoose et al., 2010).

Primary, or directly emitted, biological particles are diverse and include bacteria, fungal spores and fragments, viral particles, pollen, and plant debris. Number concentrations near the surface are generally $\sim 1-100 \mathrm{~L}^{-1}$ for individual types and can sometimes reach as high as $1000 \mathrm{~L}^{-1}$ for all biological particles $>0.4 \mu \mathrm{m}$ in diameter (Jaenicke, 2005). Given the differences in their size and source regions, biological particles have varying lifetimes and are unevenly distributed throughout the atmosphere. Perring et al. (2015) measured a wide range of fluorescent (potentially biological) particle types at low altitudes across the southern United States and found that they comprised about onefourth of the number concentration of particles larger than $1 \mu \mathrm{m}$ in diameter. However, there are few in situ measurements of biological particle concentrations at cloud levels. Fulton (1966) found that concentrations of microorganisms usually declined with height up to the limit of their measurements, about $3 \mathrm{~km}$, in the southern United States. DeLeonRodriguez et al. (2013) reported that in air influenced by Atlantic hurricanes, about $20 \%$ of submicron particles were biological. Pratt et al. (2009) and Creamean et al. (2013) reported that biological particles sometimes comprised a large fraction of ice residuals in mid-level clouds over the western United States. However, Cziczo et al. (2013) found biological particles were essentially absent in cirrus anvil outflow from various regions. In the latter study, cirrus crystal residual nuclei were found to be primarily mineral dust and industrial metals. Twohy (2014) also found that anvil cirrus from Atlantic tropical storms contained mostly mineral dust and industrial metals.

While mineral dust mass is dominated by supermicron particles, dust number concentration is dominated by submicron particles (Weinzierl et al., 2009; Chen et al., 2011). Thus, atmospheric motions can sometimes bring dust particles to the upper troposphere where cirrus clouds form. Primary biological particles tend to be less numerous in the atmosphere and are usually supermicron in size (Schneider et al., 2011; Després et al., 2012), and so they are expected to be present in relatively low quantities at high altitudes. However, biological particles may be critical to generating first ice at intermediate altitudes in mixed-phase clouds, since mineral dust becomes a less efficient ice nucleator at temperatures warmer than about $255 \mathrm{~K}$ (Murray et al., 2012).

What are the concentrations and types of biological particles as a function of height, or temperature, in the atmosphere? Aerosol particles are ubiquitous in the planetary boundary layer because they usually have surface sources, and the stable boundary-layer cap tends to keep them there. However, convective air motions can sometimes lift even supermicron particles above the boundary layer, as evidenced by Asian or Saharan dust storms. In addition to their icenucleating properties, both dust and biological particles are known to act as cloud condensation nuclei due to their relatively large sizes and their ability to absorb or adsorb water (Möhler et al., 2007; Twohy et al., 2009; Kumar et al., 2011). Thus, their abundance at higher altitudes will be influenced not only by their source strength, vertical lifting, and sedimentation rate but also by their rate of removal in precipitating cloud systems.

Determining the importance of biological particles to atmospheric ice-phase transitions is difficult due to the limited data on lofted biological material at altitudes where temperatures are below $273 \mathrm{~K}$. An additional source of uncertainty for the role of biological particles in clouds is their huge range of ice-nucleating characteristics, with number fractions for ice-nucleating types ranging between about $10^{-7}$ at $270 \mathrm{~K}$ and as high as 1 at $250 \mathrm{~K}$ for certain ice-nucleating bacteria (Després et al., 2012). The situation is additionally complicated by indications that ice-nucleating material of biological origin also can be present in submicron particles that could be more easily lofted in the atmosphere. Based on filtration of melted hailstones and decaying leaf litter, substantial ice-nucleating material was found to be smaller than $100 \mathrm{~nm}$ in size (Vali, 1966; Schnell and Vali, 1973). More recently, Pummer et al. (2012) and O'Sullivan et al. (2015) have noted the presence of ice nucleation active macro-molecules that can be extracted from pollen and fungi. Wilson et al. (2015) identified ice-nucleating material from the sea surface microlayer that passed through a $200 \mathrm{~nm}$ filtration system, found similar INPs in diatom exudates, and proposed phytoplankton exudates as INP sources. It is not clear whether these ice-nucleating entities would display fluorescence, a characteristic commonly used to indicate primary biological origin. Despite these indications that small particles might be involved in ice nucleation, a recent paper by Mason et al. (2016) showed that the majority of INPs in the atmosphere at six different North American sites were supermicron in size.

Biological particles are difficult to measure in situ, especially at the lower concentrations present far from surface sources. A fast-response instrument based on fluorescence, the Wideband Integrated Bioaerosol Sensor (WIBS-4A), was used to measure fluorescent biological aerosol particles in real time on an aircraft in September and October 2013. Particles 0.8 to $12 \mu \mathrm{m}$ (both fluorescent and non-fluorescent) were measured at temperatures of about 280 to $220 \mathrm{~K}$, ranging 
from the boundary layer to the upper troposphere, over the United States Great Plains region. Flights were mostly over undeveloped grassland or cropland toward the end of the growing season, with one flight over a forested site. To our knowledge, these are the first vertical profiles of fluorescent biological aerosol particles (FBAPs) presented over a wide range of temperatures where ice is known to form. Filter samples for determining INP number concentration vs. temperature spectra were also collected on the aircraft and at a heritage ground-based site. Vertical distribution of biological aerosol particles in the same region derived from a global chemistry-climate model were compared to the aircraft measurements of FBAPs to test model predictions. Finally, concentrations of ice-nucleating particles estimated from WIBS4A measurements were compared to typical concentrations of ice crystals at mixed-phase cloud temperatures. While this technique has substantial uncertainty, since there may be biogenic INPs that do not fluoresce or are not large enough to be detected by the WIBS-4A, it provides a reasonable first step for quantifying the potential influence of FBAPs on ice nucleation in this region of the atmosphere.

\section{Aerosol extinction profiles at the Atmospheric Radiation Measurement (ARM) Southern Great Plains site}

Kafle and Coulter (2013) presented seasonally averaged aerosol optical properties at various ARM program sites based on micropulse aerosol lidar data. They found that while most aerosol particles were confined to the boundary layer, some particles were detected above it up to the extent of their analysis $(4 \mathrm{~km})$. To evaluate the tendency for particles to escape the boundary layer over the United States Great Plains states, we analyzed data for the ARM Southern Great Plains site in northern Oklahoma up to $10 \mathrm{~km}$ altitude. Figure 1a shows aerosol extinction as a function of height for each season, averaged over non-cloudy days for the 2007-2010 period. Aerosol particles are present up to $5-6 \mathrm{~km}$ in most seasons, well above the typical daytime boundary-layer depth of $2 \mathrm{~km}$ or less (Kafle and Coulter, 2013). Figure 1b shows the standard deviation of the aerosol profile as a function of height during autumn, the same season as the aircraft sampling described later. There is substantial variability from day to day in the aerosol loading during the season, with about a third of the extinction profiles substantially above or below the mean profiles. While aerosol extinction is usually dominated by sub-micron particles, larger particles generated from local sources or long-range transport (Mishra et al., 2013) also may reach these mid-tropospheric heights.

Figure $1 \mathrm{c}$ shows the mean $24 \mathrm{~h}$ temperature profiles corresponding to the same time period as the ARM site aerosol profiles in Fig. 1a and b. The profiles demonstrate that in this location, mean boundary-layer temperatures are always warmer than freezing, so ice is unlikely to form in clouds near the surface. At $2 \mathrm{~km}$, mean temperatures range from 272 to $287 \mathrm{~K}$, depending on season, while at $5 \mathrm{~km}$ temperatures drop to $255-267 \mathrm{~K}$. The $2-5 \mathrm{~km}$ altitude range is of critical importance in this region, because this is not only where aerosol particles are relatively abundant in the free troposphere but also where temperatures may be cold enough for biological particles to nucleate ice (for example, Murray et al., 2012). FBAP measurements described later in this paper were taken farther north in Colorado, Wyoming, North Dakota, and Nebraska. For comparison, seasonally averaged surface temperatures at Boulder, Colorado, are about $2-5 \mathrm{~K}$ colder than at the ARM site.

\section{Methods}

\subsection{Experiment}

Particles were observed using the US National Science Foundation's Gulfstream V (G-V) aircraft during the Instrument Development and Education in Airborne Science (IDEAS) 2013 field program. The goals of the program were to improve the capability of instrumentation for future National Science Foundation airborne deployments and to provide opportunities for students to learn about observational science. Data from five flights between 26 September 2013 and 21 October 2013 were used to examine fluorescent biological particle concentrations as a function of height in clear air. Figure 2 shows the location of the sampling during the flights, superimposed on a 2010 land use map from the United States Geological Survey. The aircraft was based near Denver, Colorado, and the flight tracks were usually to the north and east over rural Wyoming, Nebraska, and South Dakota. One flight was over a forested site, while other flights were over arid areas and cropland and downwind of forest, shrubland, cropland, and some urban areas. In addition to the real-time WIBS-4A measurements, filter samples were collected on several flights and at the ground-based forested site while the aircraft flew overhead. These samples were later subjected to extraction and analysis for ice-nucleating particles using an immersion freezing method (Hill et al., 2014).

\subsection{Aircraft sampling}

To enhance the concentrations of supermicron particles before measurement, a National Center for Atmospheric Research counterflow virtual impactor (CVI) with the counterflow turned off was used as a sub-isokinetic inlet (Krämer and Afchine, 2004). The CVI inlet was made of titanium and was mounted on the bottom of the G-V aircraft where the airflow is less disturbed by the shape of the aircraft itself (King, 1984), with its entry tip $6.4 \mathrm{~m}$ behind the aircraft nose and $0.28 \mathrm{~m}$ away from the fuselage skin. Under sub-isokinetic conditions, the smallest particles follow streamlines when entering the inlet, while larger (generally supermicron) particles deviate from the streamlines and are concentrated inside 
(a)

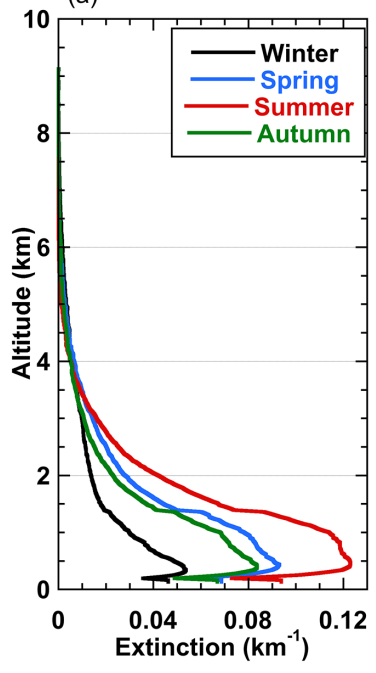

(b)

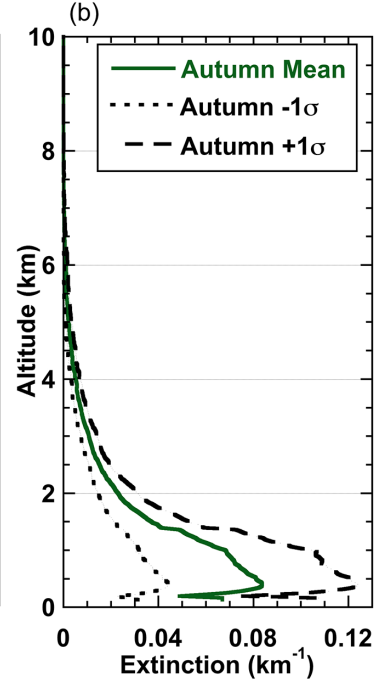

(c)

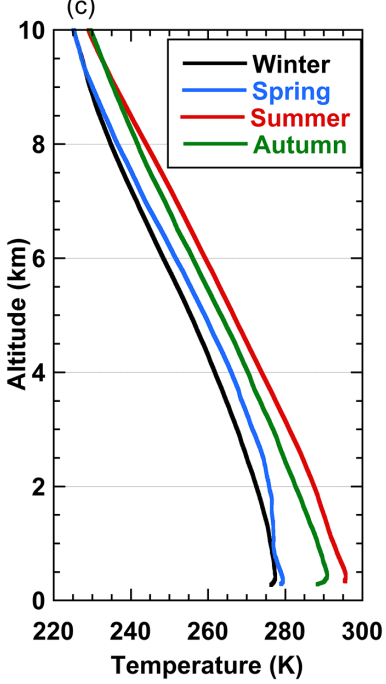

Figure 1. DOE ARM Southern Great Plains site (a) aerosol extinction coefficients as a function of altitude above ground (km) and season for non-cloudy days. Aerosol profiles were derived using multifilter rotating shadowband radiometer (MFRSR) aerosol optical depth data (Harrison et al., 1994) as input. Since these are only directly available during daytime, in order to calculate seasonal averages, nighttime values are assumed using a linear interpolation between lidar values calculated for late afternoon and the following early morning. (b) Aerosol extinction coefficient and corresponding $1 \sigma$ standard deviation for the autumn season; $1 \sigma$ standard deviations are given in broken lines. (c) Temperature profiles from the ARM Balloon-Borne Sounding System (SONDE) observations (Holdridge et al., 2011) as a function of altitude for non-cloudy days.

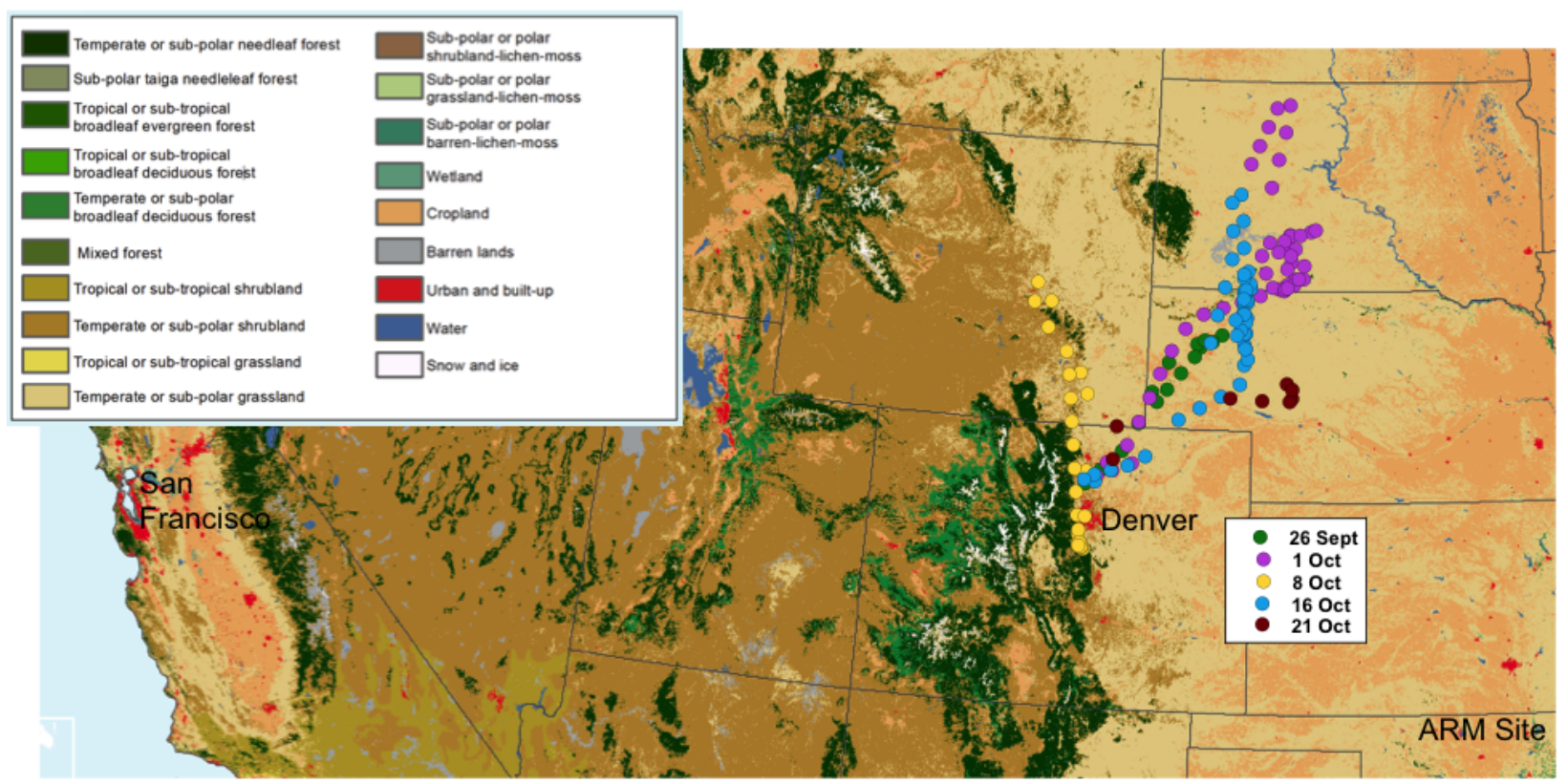

Figure 2. Location of clear-air sampling on five flights during the IDEAS-2013 field program. Each colored dot on the right shows the location of $200 \mathrm{~s}$ averaged WIBS-4A data for the dates shown in 2013. Location where aerosol extinction data shown in Fig. 1 were taken (Oklahoma ARM site) is noted at lower right. Map colors show the 2010 North American Land Cover at $250 \mathrm{~m}$ spatial resolution for sampling and upstream regions. Produced by Natural Resources Canada/the Canada Centre for Mapping and Earth Observation (NRCan/CCMEO), United States Geological Survey (USGS); Insituto Nacional de Estadística y Geografía (INEGI), Comisión Nacional para el Conocimiento y Uso de la Biodiversidad (CONABIO), and Comisión Nacional Forestal (CONAFOR). 
the inlet. Computational fluid dynamics modeling was used to calculate aspiration efficiency and transmission efficiency of the sub-isokinetic inlet as a function of particle size for two different aircraft speed cases, simulating low- and highaltitude sampling. A detailed aerosol transport model (von der Weiden et al., 2009) was then used to calculate transmission efficiency in the plumbing downstream of the inlet itself. The net inlet efficiency (aspiration and transmission) as a function of particle size and airspeed was then applied to the particle measurements to correct them back to ambient atmospheric conditions, as presented below. Further details of these calculations and assumptions therein are presented in Appendix A.

\subsection{Fluorescent biological particle measurements}

The Droplet Measurement Technologies WIBS-4A was used to perform real-time measurements of FBAPs from the aircraft. Most biological particles contain compounds that fluoresce at wavelengths detected by this technology, and most nonbiological particles fluoresce more weakly or at different wavelengths. Therefore the WIBS-4A may be used to distinguish fluorescent particles that are predominantly biological from non-fluorescent particles that are predominantly nonbiological (Pöhlker et al., 2012; Huffman et al., 2013). Particles containing mixtures of biological and nonbiological material may also be classified as FBAPs when their fluorescent signal is sufficiently strong. The WIBS-4A measured fluorescent emissions on a single particle basis for two ultraviolet (UV) excitation wavelengths and in two emission windows (Kaye et al., 2005; Perring et al., 2015). Particles were first sized using elastically scattered light from a $635 \mathrm{~nm}$ diode laser, which also served as a trigger for the fluorescence measurements. Two filtered Xenon flashlamps $(\mathrm{Xe} 1=280 \mathrm{~nm}$, $\mathrm{Xe} 2=370 \mathrm{~nm}$ ) were then fired in sequence and any resulting fluorescence was monitored by two photomultiplier tubes filtered to measure light between 310 and $400 \mathrm{~nm}$ (FL1) and between 420 and $650 \mathrm{~nm}$ (FL2). Flashlamp timings were optimized using $2 \mu \mathrm{m}$ fluorescent polystyrene latex spheres (Thermo Scientific). The Xenon flashlamps were limited to an upper rate of approximately $125 \mathrm{~Hz}$ due to recharging requirements, so final particle concentrations were corrected for any particles missed during recharge periods.

The combination of two excitation wavelengths and two emission windows provides three useful channels of fluorescence information (Perring et al., 2015). Channel A (previously referred to as FL1_280) is defined as $280 \mathrm{~nm}$ excitation and 310-400 nm emission; Channel B (FL2_280) is defined as $280 \mathrm{~nm}$ excitation and $420-650 \mathrm{~nm}$ emission, and Channel C (FL2_370) is defined as $370 \mathrm{~nm}$ excitation and $420-650 \mathrm{~nm}$ emission. Particles were classified as fluorescent when they emitted light in a single channel or combination of channels. Forced trigger measurements were performed at the beginning and end of each flight, during which time the instrument fired the UV light sources in the absence of particles to measure the background signal. The background signal averages and standard deviations were linearly interpolated over each flight. Only fluorescent signals larger than the forced-trigger average value plus 2.5 standard deviations are included in the data presented here.

Seven possible combinations of fluorescent emission response are possible (A only, $\mathrm{B}$ only, $\mathrm{C}$ only, $\mathrm{AB}$ but not $\mathrm{C}, \mathrm{AC}$ but not $\mathrm{B}, \mathrm{BC}$ but not $\mathrm{A}$, and $\mathrm{ABC}$ ). The use and understanding of these channel combinations to define fluorescent biological particle types is still maturing within the WIBS user community. Fluorescence in both channels A and $\mathrm{C}$ correlates with the presence of both the amino acid tryptophan and the coenzyme NADH (nicotinamide adenine dinucleotide), likely indicating actively metabolizing organisms such as bacterial cells (Pöhlker et al., 2012). Therefore, in previous work focusing on interpretation of WIBS fluorescent signals, the $\mathrm{AC}$ and $\mathrm{ABC}$ channels have been combined into a category sometimes called FBAP or FL13 (Gabey et al., 2011). This has been considered to be a conservative estimate for fluorescent biological particles, though other interpretations of the signals have also been applied (e.g., Wright et al., 2014). More recently, Perring et al. (2015) used all categories of fluorescent particles to present a more inclusive interpretation of the WIBS-4A data. In the Results section, we present two different FBAP concentrations ("low" and "high") to represent the uncertainty currently inherent in measuring biological particles via this fluorescent method. The lower bound or conservative estimate encompasses only particles that fluoresce in both channels A and C (formerly FL13) and facilitates comparisons with many earlier measurements. The high, or expected, upper bound of FBAPs presented here includes all categories of particles fluorescing in channels A or $\mathrm{C}$. We preclude particles fluorescing in Channel B only, since this channel may be influenced by anthropogenic, nonbiological particles (Gabey et al., 2011; Toprak and Schnaiter, 2013), and background fluorescence signal for this channel was higher than usual in the particular instrument used.

The WIBS-4A deployed for IDEAS was modified to provide better flow control and measurement for operation behind the CVI. The total flow was regulated by an Alicat mass flow controller operating in volumetric mode. The total volumetric sample flow was converted to a 0-10 VDC signal and passed to the CVI data system to provide real-time control based on instrument flows. The WIBS-4A was located near the middle of a standard $1.27 \mathrm{~m}$ high G-V rack and connected to the sampling inlet with stainless steel and conductive silicon tubing. Based on size-dependent concentration corrections for inlet aspiration and transmission efficiency described in Appendix A, net efficiency for particles larger than $12 \mu \mathrm{m}$ diameter was less than $2 \%$. Detection of fluorescent particles smaller than 0.8 in diameter is limited by the sensitivity of the WIBS-4A detectors (Gabey et al., 2010). Therefore, when presenting measured concentrations or properties of FBAPs, only particles between 0.8 
and $12 \mu \mathrm{m}$ in diameter are represented. This upper cut size means that our results will not include intact pollen grains, but pollen number concentrations are typically order of magnitudes smaller than those for bacteria and fungal spores near the surface (Després et al., 2012), so this omission is not likely to be significant. Additionally, the model results described in Sect. 4.3 predict that pollen number concentrations were always less than $0.4 \%$ of bacteria and fungal spores concentrations at all altitudes in the IDEAS sampling region.

Sizing calibration was checked before the project using $2 \mu \mathrm{m}$ polystyrene latex spheres, a size that is representative of the peak size ( $2-3 \mu \mathrm{m}$ diameter) for the measured fluorescent particles. However, calibration may deviate by as much as $20 \%$ for larger sizes, and variation in scattering with size can be $\pm 15 \%$ (A. Perring, personal communication, 2015). In addition, biological particles may have different shapes and refractive indices from polystyrene spheres. Therefore, net uncertainty in sizing of fluorescent biological particles via the WIBS-4A may be as high as $50 \%$. This corresponds to about a $40 \%$ error in the size-dependent concentration corrections for inlet aspiration and transmission efficiency described in Appendix A. The $1 \mathrm{~Hz}$ clear-air WIBS-4A data were averaged over $200 \mathrm{~s}$ of flight time to reduce uncertainty at low particle concentrations. With the sub-isokinetic enhancement factor, this corresponds to about $5 \mathrm{~L}$ of particles collected during each sampling period. WIBS-4A concentrations are reported in ambient (not standard) $\mathrm{L}^{-1}$, for consistency with accepted reporting of ice crystal number concentrations in the cloud physics literature. Error bars on the number concentration plots represent the root-sum squared (RSS) uncertainty from three main sources: (1) counting statistics, (2) WIBS-4A concentration errors, and (3) uncertainty in inlet efficiency calculations. For the first, we use $N^{\frac{1}{2}}$ for positive counts and $(N+1)^{\frac{1}{2}}$ for zero counts (FDA, USGS, and NIST, 2004). For the second, we estimate $20 \%$ due primarily to forced-trigger baseline uncertainty. The RSS uncertainty of the calculated inlet efficiency is $53 \%$ (incorporates $40 \%$ due to the WIBS-4A sizing uncertainty given above and $35 \%$ estimated uncertainty in model efficiency calculations). Propagated concentration uncertainty varies with concentration magnitude but is less than $60 \%$ in most cases. This is usually much smaller than the difference in concentrations resulting from the conservative and liberal approaches in defining FBAPs, as described earlier.

\subsection{INP filter samples}

Particles were collected onto filters and then re-suspended in water for measurement of INPs using the immersion freezing method. INP measurements used the Colorado State University ice spectrometer (Hill et al., 2014; Hiranuma et al., 2015a), a device in which an array of liquid aliquots in a temperature-controlled block can be monitored for freezing events as temperature is decreased.
Filters used were $0.2 \mu \mathrm{m}$ pore diameter, $47 \mathrm{~mm}$ diameter

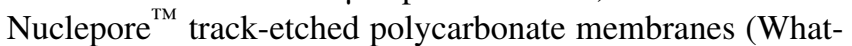
man, GE Healthcare Life Sciences). Filters were cleaned before sampling by immersion in $15 \% \mathrm{H}_{2} \mathrm{O}_{2}$ for $10 \mathrm{~min}$, followed by two rinses in deionized water $(18 \mathrm{M} \Omega$ and $0.2 \mu \mathrm{m}$ diameter pore filtered) and one rinse in deionized water that had been filtered through a $0.02 \mu \mathrm{m}$ pore diameter syringe filter (Anotop, Whatman, GE Healthcare Life Sciences), then dried on foil and loaded into filter units with sterile tweezers. All preparations were performed in a laminar flow cabinet $\left(<0.01\right.$ particles $\left.\mathrm{mL}^{-1}\right)$. On the $\mathrm{G}-\mathrm{V}$ aircraft, $47 \mathrm{~mm}$ inline aluminum filter housings (Pall Corporation) were used to contain sampling filters. These units were cleaned before use by disassembly, immersion in $10 \% \mathrm{H}_{2} \mathrm{O}_{2}$ for $30 \mathrm{~min}$ followed by three rinses in deionized water $(18 \mathrm{M} \Omega$ and $0.2 \mu \mathrm{m}$ diameter pore filtered), and then dried by removal of excess water and placement on foil in a laminar flow cabinet. Aircraft filters were operated at $5 \mathrm{~L} \mathrm{~min}^{-1}$ through a $0.48 \mathrm{~cm}$ inner diameter stainless steel line that connected to the CVI. Collection onto the surface or into the pores of the Nuclepore filters should have exceeded $90 \%$ for all particle sizes at the flow rates used on the basis of filter specification and theoretical collection efficiencies (Spurny and Lodge, 1972). After particle collection, filters were stored frozen in sealed sterile petri dishes until processed.

During ground-based sampling at the forested site on 8 October 2013, open-faced Nalgene sterile filter units (Thermo Fisher Scientific Inc.) were pre-loaded with the same type of Nuclepore filters as used on the aircraft. Sampling was conducted over a period (11:34 to $\sim 14: 30$ MST) that encompassed the time of the aircraft overpasses (12:50 to 13:25 MST). One filter unit was placed $14 \mathrm{~m}$ above ground and sampled with a flow rate of $8.5 \mathrm{~L} \mathrm{~min}^{-1}$, while the other was placed $1 \mathrm{~m}$ above ground, sampling at $9.0 \mathrm{~L} \mathrm{~min}^{-1}$. Units were returned intact on ice and stored at $-20^{\circ} \mathrm{C}$ until processed.

For processing, filters were transferred to sterile, $50 \mathrm{~mL}$ Falcon polypropylene tubes (Corning Life Sciences), immersed in $5.0 \mathrm{~mL}$ of $0.02 \mu \mathrm{m}$ pore diameter filtered deionized water, and tumbled for $30 \mathrm{~min}$ at 60 cycles $\mathrm{min}^{-1}$ in a rotator (Roto-Torque, Cole-Palmer) to re-suspend particles. Measurements of immersion freezing by the re-suspended particles were made on this suspension and 15-fold dilutions of it to extend measurements to lower temperatures. Liquid suspensions were distributed into 32 aliquots of volume $80 \mu \mathrm{L}$ in 96-well PCR trays ( $\mu$ Cycler, Life Science Products), which were then capped with polystyrene lids (Nunc microwell plates, Thermo Fisher Scientific Inc.) and transferred to the ice spectrometer. The numbers of wells frozen were counted at 0.5 or $1{ }^{\circ} \mathrm{C}$ intervals during cooling at a rate of $-0.3{ }^{\circ} \mathrm{C} \mathrm{min}^{-1}$, and cumulative numbers of INPs per volume of liquid as a function of temperature were estimated using the formula $-\ln f_{\mathrm{u}}(T) / V$, where $f_{\mathrm{u}}(T)$ is the unfrozen fraction at a given temperature and $V$ is an aliquot volume (Vali, 1971). This formula accounts for the fact that each 
aliquot may hold more INPs than the first one that freezes. Correction for any frozen aliquots in the water used for suspension was made in all cases. Uncertainties are given as binomial sampling confidence intervals (95\%) (Agresti and Coull, 1998). Conversion to INP number concentrations in ambient $\mathrm{L}^{-1}$ was made using the sample volumes and correcting for the inlet aspiration and transmission efficiency discussed in the Appendix for the aircraft samples.

Two blank filters were also collected during aircraft flights and analyzed to constrain the influence of possible contamination during sampling. This was necessitated by the fact that the sample volumes for aircraft filters were much smaller than the $\sim 2000 \mathrm{~L}$ collected by ground-based filters. Since INPs released from the blank filters differed, corrections for and tests of significance between sample and blank INPs at each temperature were performed separately for each blank. Tests of significance between sample and blank used Fisher's exact test (Fisher, 1922) to derive exact $p$ values for the likelihood of the difference in proportions of wells unfrozen (i.e., not containing an INP) between sample and blank at each temperature.

The $p$ value is given by

$p=\frac{(a+b) !(c+d) !(a+c) !(b+d) !}{a ! b ! c ! d ! n !}$,

where $a$ and $b$ are the numbers of wells unfrozen and frozen, respectively, in the sample, and $c$ and $d$ are the same for the blank, at each temperature. $n$ is the combined total number of aliquots being tested in both samples.

\subsection{Global chemistry-climate model}

The global chemistry-climate model ECHAM5/MESSy Atmospheric Chemistry (EMAC) (ECHAM version 5.3.01, MESSy version 1.9; Jöckel et al., 2005) was used to simulate the emissions and transport of biological particles. Model simulations were conducted in T63L31 resolution (i.e., $210 \mathrm{~km} \times 210 \mathrm{~km}$ at the Equator, with 31 vertical levels up to a model top of $10 \mathrm{hPa}$ ). The model dynamic scheme was weakly nudged (Jeuken et al., 1996; Jöckel et al., 2006; Pozzer et al., 2012) towards the analysis data of the European Centre for Medium-Range Weather Forecasts (ECMWF) operational model (up to $100 \mathrm{hPa}$ ), such that the meteorology in the model results shown here is consistent with the time period during which the campaign took place. The model simulation was initialized for 1 January 2012, to allow ample spin-up time. Simulation results were used from the times of the aircraft flights in September and October of 2013.

Bacteria emissions were calculated using the best-estimate number fluxes from Burrows et al. (2009b) with the minor modification that the flux from land ice was set to zero. Fungal spore emissions were calculated following Heald and Spracklen (2009) and pollen emissions were calculated following Jacobson and Streets (2009). The following geometric mean diameters $(d)$ were assumed for the different par- ticle classes. For bacteria, d was set to $4 \mu \mathrm{m}$ (continental sources) or $2.4 \mu \mathrm{m}$ (marine sources), following values reported for the count median diameter of bacteria-carrying particles, which may include bacteria borne on larger particles such as dust and leaf litter and/or clumps of bacteria (Shaffer and Lighthart, 1997; Tong, 1999; Tong and Lighthart, 2000; Wang et al., 2007). For fungal spores, $d=$ $4 \mu \mathrm{m}$ (Hussein et al., 2013) was used, and for pollen, $d=$ $20 \mu \mathrm{m}$ (Niklas, 1985; Di-Giovanni et al., 1995).

All particle classes were treated as having a lognormal distribution with modal-scale parameter $\sigma=1$ and with a density of $1 \mathrm{~g} \mathrm{~cm}^{-3}$. Further, all particles were active as cloud condensation nuclei when calculating particle removal processes, as described in Burrows et al. (2009a). The sensitivity of particle transport and removal processes to these and other model parameters has been characterized in detail for an earlier version of the EMAC model (Burrows et al., 2013). All biological particles were transported as passive tracers, i.e., their concentrations were influenced by model processes (such as precipitation scavenging), but bioaerosols did not interact with radiation or influence cloud microphysical properties. The sedimentation and dry deposition of the particles are treated as described in Kerkweg et al. (2006). The wet deposition of the particles is described in Tost et al. (2006).

\section{Results}

\subsection{Comparison with ground and tower data at forested site}

A previous ground-based study, Bio-hydro-atmosphere interactions of Energy, Aerosols, Carbon, $\mathrm{H}_{2} \mathrm{O}$, Organics \& Nitrogen - Rocky Mountain Biogenic Aerosol Study (BEACHON-RoMBAS; Ortega et al., 2014), was conducted in July-August 2011 at the Manitou Experimental Forest Observatory (MEFO) site near Woodland Park, Colorado. The concentrations of ice-nucleating particles measured by a droplet freezing apparatus and by a continuous-flow diffusion chamber were found to be correlated with concentrations of biological particles at this forested site (Huffman et al., 2013; Tobo et al., 2013). In addition, Prenni et al. (2013) and Crawford et al. (2014) found enhanced bioaerosol concentrations after rain events in this region.

During IDEAS, the aircraft flew over the same MEFO site on 8 October 2013. First, we present fluorescent biological particle concentrations and INP concentrations from filter measurements taken on the aircraft over the forested site and compare them with similar measurements taken simultaneously on the ground and at the canopy top. The aircraft spiralled down over the ponderosa pine site from 3638 to $897 \mathrm{~m}$ aboveground level, near midday. Figure 3a shows that about $10-60 \mathrm{~L}^{-1}$ of $0.8-12 \mu \mathrm{m}$ particles were fluorescent above the forest canopy, with a sharp decline above the top of the temperature inversion at about $1.7 \mathrm{~km}$. WIBS-4A FBAP 

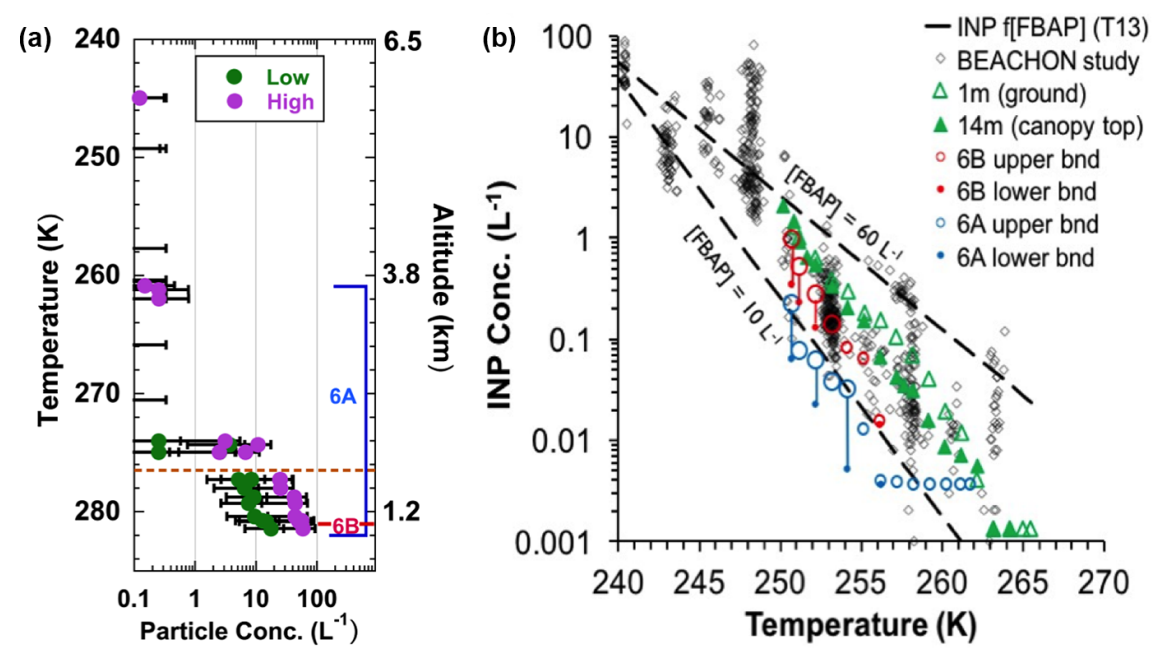

Figure 3. (a) FBAP number concentration profile vs. temperature over the MEFO experimental site on 8 October 2013 as described in the text. Green and magenta circles are for low and high FBAP values, respectively, based on different definitions of which fluorescent particles are biological as discussed in the text. Top of the temperature inversion is marked with the dashed orange line. 6A is the location of the sample filter taken on the descent to 3638 to $897 \mathrm{~m}$ above the ground at the forested site, while $6 \mathrm{~B}$ is the filter taken at $1067 \mathrm{~m}$. Error bars represent root-sum-square uncertainty as described in the text. (b) Filter-based INP spectra at $1 \mathrm{~m}, 14 \mathrm{~m}$, and for aircraft samples $6 \mathrm{~A}$ and 6B. Upper and lower bounds are placed on the aircraft INP samples as discussed in the paper, and vertical lines connect common upper and lower bounds. Large data points in blue and red indicate data that passed a test for significance in comparison to filter blank INP numbers. Filter-based INP data are superimposed on previous data (grey diamonds) from a continuous-flow diffusion chamber at the experimental site (Tobo et al., 2013). The two dashed lines denote INP concentrations from the FBAP to INP parameterization of Tobo et al. (2013), using the low and high values of FBAPs measured by the WIBS-4A aboard the aircraft at the lower altitudes $\left(10\right.$ and $\left.60 \mathrm{~L}^{-1}\right)$.

measurements at the lowest altitudes are similar to those measured earlier by another fluorescent-based instrument, an ultraviolet aerodynamic particle sizer (UV-APS, TSI manufacturer) at the same site (Schumacher et al., 2013). Using the UV-APS, Schumacher et al. (2013) measured mean FBAP concentrations $\left(>1.0 \mu \mathrm{m}\right.$ diameter) of about $30 \mathrm{~L}^{-1}$ in summer and $17 \mathrm{~L}^{-1}$ in autumn of 2011 at $4 \mathrm{~m}$ a.g.l. The UV-APS uses a single excitation wavelength of $355 \mathrm{~nm}$, similar to the WIBS-4A channel C, to measure FBAPs. This encompasses four WIBS-4A fluorescent categories (Sect. 3.3): $\mathrm{C}, \mathrm{AC}, \mathrm{BC}$, and $\mathrm{ABC}$. Therefore, neglecting other technical differences in the instruments, our conservative ("low") and liberal ("high") results should bound the prior UV-APS results, and do so for this case. The UV-APS measures FBAPs $>0.5 \mu \mathrm{m}$ diameter and the WIBS-4A $>0.8 \mu \mathrm{m}$ diameter, but this is a minor difference since Schumacher et al. (2013) found that nearly all FBAPs measured by the UV-APS at the MEFO site were larger than $1 \mu \mathrm{m}$ in size.

Figure 3a also shows the atmospheric temperatures over which filters were collected on the aircraft for offline INP spectral analysis. One filter (6A) was collected over a range of altitudes as the aircraft spiralled down over the ground site, and another (6B) was taken while flying level at $1067 \mathrm{~m}$ a.g.l. in a racetrack pattern over the site, within the atmospheric boundary layer. Sample volumes were $\sim 37 \mathrm{~L}$ for $6 \mathrm{~B}$ and $\sim 142 \mathrm{~L}$ for $6 \mathrm{~A}$. Figure $3 \mathrm{~b}$ shows INP temperature spectra from the offline filter analysis. As discussed above, two near- surface filters were collected simultaneously with aircraft filter samples 6A and 6B: one at $1 \mathrm{~m}$ above the ground and one in a tower at $14 \mathrm{~m}$. INP spectra determined from the $1 \mathrm{~m}$ and $14 \mathrm{~m}$ filters (green triangle points) are very similar to each other. The INP spectra for the aircraft filters are shown as upper-bound (open points) and lower-bound (filled points) data, in blue and red, respectively, for samples $6 \mathrm{~A}$ and 6B in Fig. 3b. The bounding values are based on subtracting the "background" or contamination INP numbers of the blank filters from the observed INP numbers per filter. Upper INP bounds were derived by subtraction of the cleaner of the two blanks and lower bounds by subtraction of the more contaminated blank. Upper- and (positive) lower-bound data are connected with vertical lines to give a sense of the range of likely INP number concentrations from the collections made at altitude. Data points fulfilling a Fisher's exact test for significance (Sect. 3.4) between samples and background are plotted as the largest points; these points were all upper-bound points. These data present a large uncertainty but indicate that INP number concentrations at $1067 \mathrm{~m}(6 \mathrm{~B})$ were about the same to about a factor of 4 lower than at the forest canopy top (14 m). However, the sample collected over a range of altitudes, primarily in the free troposphere, exhibited much lower INP concentrations than the boundary-layer filter (6B), by a factor of approximately 5 . These lower INP number concentrations occur in association with decreasing FBAPs (Fig. 3a) and decreasing total particle concentration 
(not shown) in the $0.8-12 \mu \mathrm{m}$ diameter range at higher altitudes. This is expected given the probable canopy source of INPs at this forested site (Crawford et al., 2014).

In Fig. 3b, INP filter-based spectra from the three lowest altitudes are also superimposed on in situ INP results obtained previously (Tobo et al., 2013) at $1 \mathrm{~m}$ using the CSU continuous-flow diffusion chamber (CFDC; light grey diamonds). The new measurements from IDEAS are quite consistent with the range of number concentrations observed using the CFDC during summer 2011. Additionally, icenucleating particle concentrations were estimated as a function of FBAP concentrations measured from the aircraft, using a recent parameterization by Tobo et al. (2013) based on the concentration of FBAPs $>0.5 \mu \mathrm{m}$ measured by a UVAPS. Using measured low-level FBAP concentrations of 10 to $60 \mathrm{~L}^{-1}$ (approximate low and high values in Fig. 3a), the INP concentrations derived from the parameterization by Tobo et al. (2013) are shown as the two dashed black lines. The predicted INP number concentrations bracket the BEACHON-RoMBAS and IDEAS data well, with all of the observed INP number concentrations falling within the estimated values.

It is important to note that while the Tobo et al. (2013) study showed that FBAPs are correlated with INPs at this site, other particle types, such as soil dust, may still be important contributors to INP number concentrations in the region, particularly at lower temperatures and for drier conditions (Prenni et al., 2013). Also, even if all the INP activity were contributed by biological particles, only a relatively small percentage of them would be expected to nucleate ice at mixed-phase cloud temperatures. For example, Fig. 3b shows that for a moderate FBAP value of $\sim 30 \mathrm{~L}^{-1}$ only about $0.01 \mathrm{~L}^{-1}$, or $0.03 \%$, of these particles would be expected to produce ice at $263 \mathrm{~K}$ and about $0.3 \mathrm{~L}^{-1}$, or $1 \%$, at $253 \mathrm{~K}$. Additionally, these numbers are based on boundary-layer measurements and only become relevant if ice-nucleating particles actually reach regions of the atmosphere with humidities and temperatures conducive to forming clouds. On this particular day, fluorescent biological particles were present at low concentrations $\left(<1 \mathrm{~L}^{-1}\right)$ at temperatures below about 272 K, where mixed-phase clouds may form (Fig. 3a). Next, we explore the variation of FBAPs with temperature measured on five different flights in the region and compare results with those of a global model. In Sect. 5, implications for ice formation at mixed-phase cloud temperatures are discussed.

\subsection{Vertical distribution of clear-air FBAPs for five flights}

Figure 4 shows the distribution of FBAPs measured as a function of ambient temperature on all five flights over Colorado, Wyoming, Kansas, and Nebraska. All flights took place during midday hours, when the convective boundary layer is expected to be near its maximum (Nilsson et al.,
2001), with its top typically at temperatures warmer than about $275 \mathrm{~K}$. Clear-air profiles show a general decrease of fluorescent biological particle concentration with decreasing temperature. Since the WIBS-4A instrument measures particles with a range of fluorescent characteristics, the expected lower bounds on FBAPs (only particles that fluoresce in both channels $\mathrm{A}$ and $\mathrm{C}$ ) are shown with green circles, and the expected upper bounds (particles with broader fluorescent characteristics as described in Sect. 3.3) are shown in magenta circles for each sampling period. These two values can differ by up to an order of magnitude at each location, indicating that more characterization studies of particle type vs. WIBS-4A response would be very valuable. Even given the uncertainty in what should be characterized as biological, important conclusions can be made. First, FBAPs were typically $\sim 10-100 \mathrm{~L}^{-1}$ at warm temperatures near the surface but much lower, between 0 and $3 \mathrm{~L}^{-1}$, at cold, cirrus cloud temperatures. For many mid- to high-altitude areas, the atmosphere was essentially devoid of fluorescent biological particles. However, two flights are of special interest. On 1 October, a wide range of FBAP concentrations was observed when the aircraft flew a $60 \mathrm{~km}$ box pattern at a constant altitude $(\sim 270 \mathrm{~K})$ for $90 \mathrm{~min}$, indicating that strong variations in FBAPs can occur in relatively small areas. On 16 October, relatively high FBAP concentrations (up to $30 \mathrm{~L}^{-1}$ for upper-bound values) were observed at temperatures as cold as $\sim 255 \mathrm{~K}$.

Figure 5 shows the clear-air data for all flights plotted together on a linear scale to highlight regions with higher FBAP concentrations. The lower-bound estimates of which fluorescing particles $(0.8-12 \mu \mathrm{m})$ are likely biological are given in the plot on the left (Fig. 5a), and the expected upper bounds on the right (Fig. 5b). The approximate homogeneous freezing region, heterogeneous nucleation region, and the warmer portion of the latter where biological INPs are expected to be most important (Murray et al., 2012) are shaded in grey, blue, and green, respectively. Upper-bound FBAP concentrations (Fig. 5b) are most variable, particularly in the $\sim 270$ to $255 \mathrm{~K}$ temperature region where they are likely most important to ice formation in mixed-phase clouds. These temperatures occurred above the atmospheric boundary layer, well above the surface where biological particles are generated. For three of the five flights, concentrations were much lower in this region of the atmosphere than in the boundary layer. However, for two flights (1 October 2013: purple; 16 October 2013: red), tens per liter of fluorescent biological particles sometimes reached higher altitudes and colder temperatures where ice might form heterogeneously. On these days, the presence of higher numbers of FBAPs suggest that the ones active as ice-nucleating particles might be able to influence mixed-phase cloud development. This possibility is explored more quantitatively in the next section.

The WIBS-4A data can also determine the size of particles both fluorescent and non-fluorescent (based on scattering of 


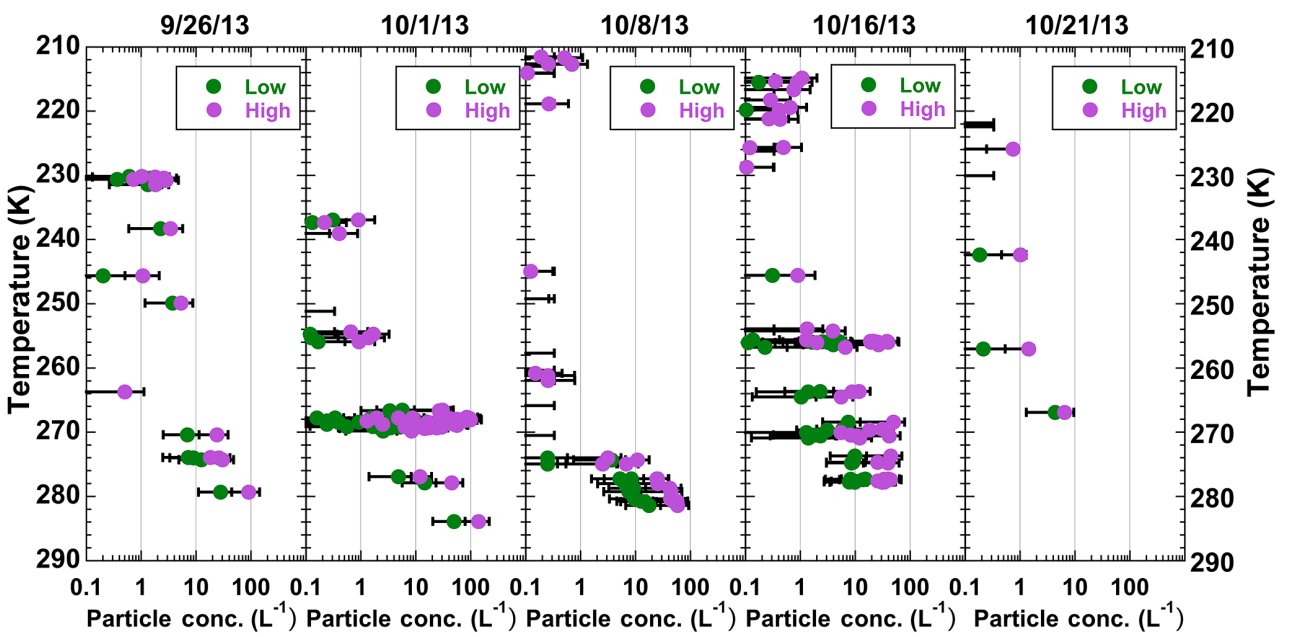

Figure 4. Clear-air temperature profiles of FBAP concentration vs. ambient temperature for each flight. Green and magenta circles are for low and high FBAP values, respectively, based on different definitions of which fluorescent particles are biological as discussed in the text. The top of the boundary-layer inversion varied with flight but was typically at temperatures warmer than $275 \mathrm{~K}$.
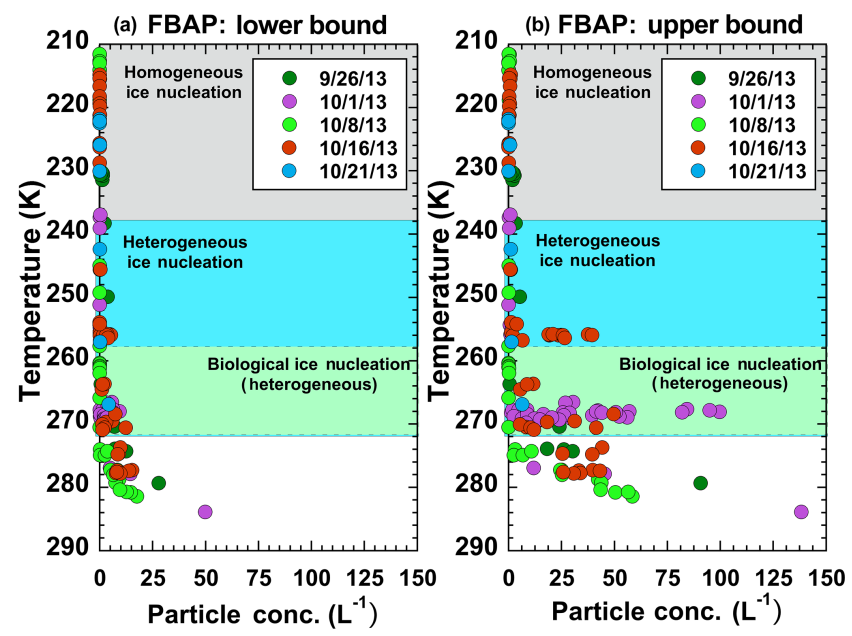

Figure 5. Vertical profiles of fluorescent biological aerosol particle concentration measured by the WIBS-4A for five flights with dates and colors shown, with approximate ice nucleation temperature ranges as discussed in the text highlighted. (a) Lower-bound values based on WIBS-4A categorization; (b) upper-bound values.

$635 \mathrm{~nm}$ light). Most of the measured fluorescent particles were relatively large, with a mode size of $\sim 2-3 \mu \mathrm{m}$, consistent with the studies at the MEFO forested site (Huffman et al., 2013). Figure 6 shows a histogram of the ratio of fluorescent particle concentration to total particle concentration $(0.8-12 \mu \mathrm{m})$ using data from all five flights. The mean percentage of all $0.8-12 \mu \mathrm{m}$ particles that fluoresced in the two WIBS-4A channels was about $3 \%$ for the conservative definition and $11 \%$ for the more liberal definition of FBAPs. This is also consistent with other studies, for example, Tobo et al. (2013).

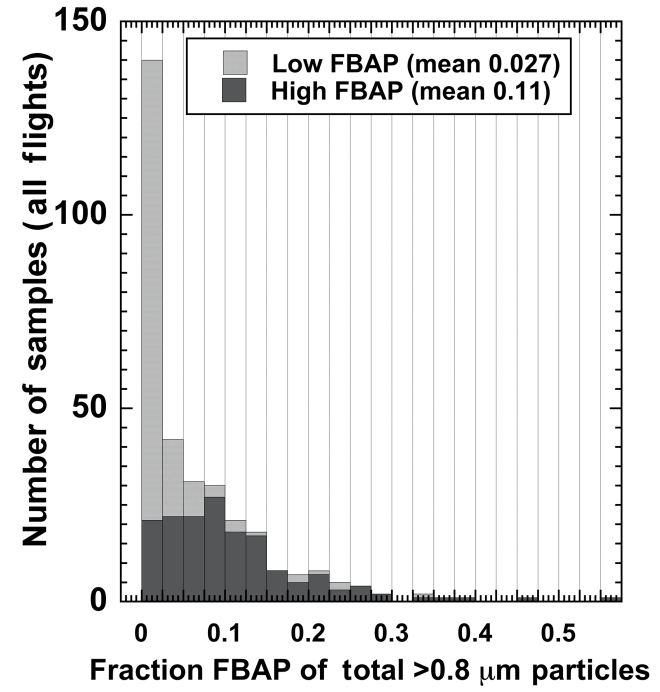

Figure 6. Ratio of FBAP number concentration to total particle number concentration in the $0.8-12 \mu \mathrm{m}$ size range, using expected low and high bounds as discussed in the text. Histograms of $200 \mathrm{~s}$ average values for WIBS-4A samples on all five flights are plotted. Legend shows the mean fraction for each FBAP category.

\subsection{Comparison with global chemistry-climate model}

The EMAC global atmospheric model simulates emissions, transport, and removal of primary biological aerosol particles (fungal spores, bacteria, and pollen). Figure 7 compares the modeled total concentrations of these three particle types with FBAP concentrations observed by the aircraft for the same 5 days, with black diamonds interpolated from the aircraft measurement altitude, location, and time. To exhibit modeled spatial variation and detailed 

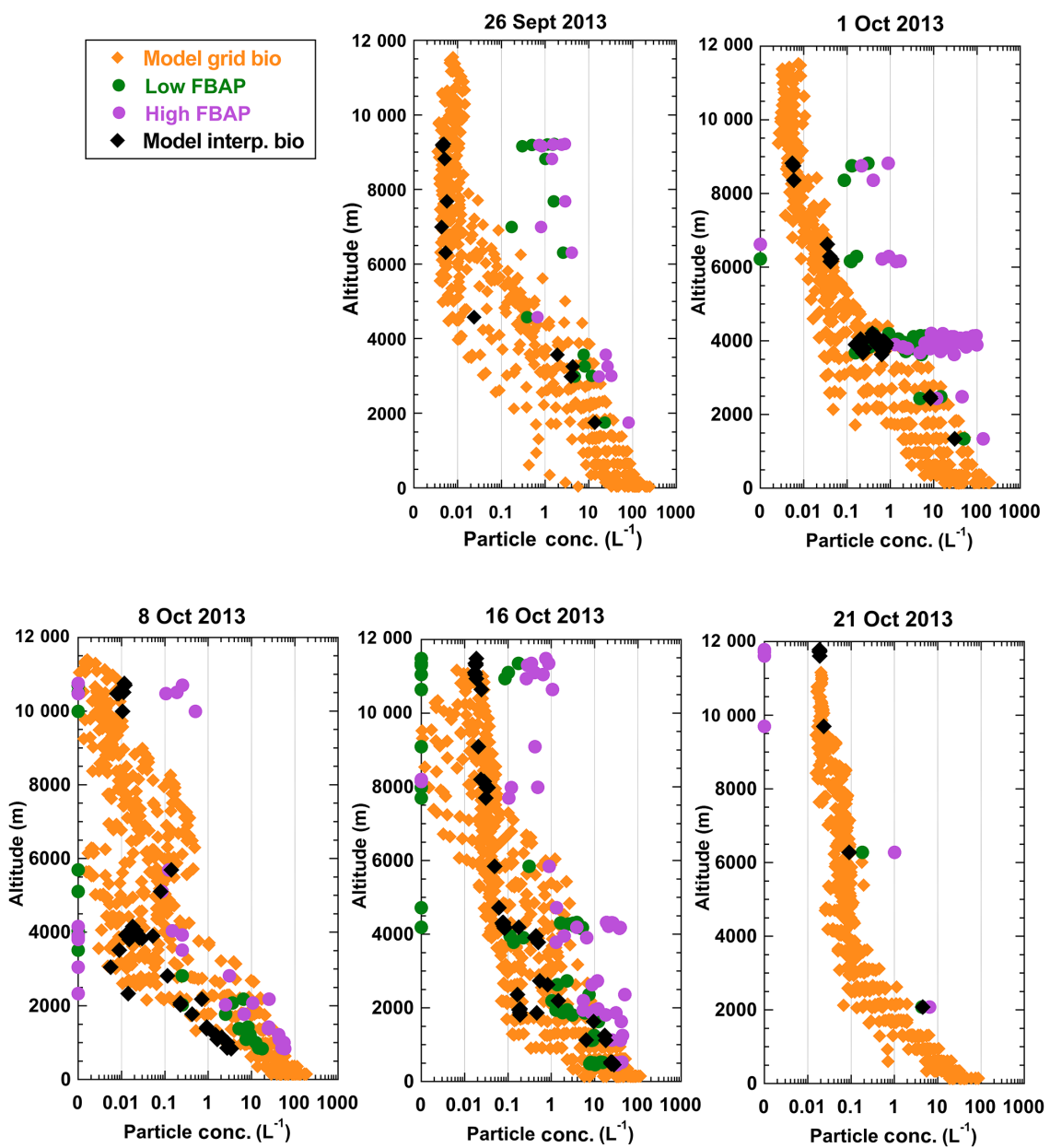

Figure 7. Model-predicted biological particle concentration $\left(\mathrm{L}^{-1}\right)$ as a function of altitude above ground for the five flights. Orange diamonds are all points in 25 grid boxes within the IDEAS domain (latitude range 37.30-46.63 ${ }^{\circ} \mathrm{N}$, longitude 107.81-98.44 ${ }^{\circ} \mathrm{W}$ ) for 18:00 UTC on each day. Black diamonds are model data interpolated to altitude, horizontal location, and time of the measurements. Green and magenta circles are the low and high FBAP values from the WIBS-4A data, as described earlier and shown in Figs. 4 and 5. Zero values are set to 0.001 so they are visible on the log plot.

vertical profiles, orange diamonds show modeled concentrations for all 25 grid boxes encompassing the entire IDEAS sampling domain at 18:00 UTC for each day. It is interesting to note that the model often predicts 1-2 orders of magnitude variability in biological particle concentration at the same altitude in different grid boxes throughout the sampling region $\left(37.30-46.63^{\circ} \mathrm{N}, 107.81-98.44^{\circ} \mathrm{W}\right)$. In general, the model simulates concentrations in the boundary layer that are within the range of what is typically observed, and the decrease in concentration with increasing altitude qualitatively agrees with the FBAP observations. However, the model frequently underpredicts observed concentrations in the free troposphere, and observed concentrations often decline with height more rapidly than the model predicts.

Possible explanations for discrepancies between the model and observations include underprediction of bioaerosol sources including via long-range transport, overprediction of the rate of removal by dry and wet deposition of particles, and underprediction of turbulent exchange between the boundary layer and the free troposphere. It is also possible that important contributions to the observed FBAPs may not be represented in the model. For instance, the model does not include representations of leaf litter or arable soil emissions, which may contribute to the observed FBAPs. Also, the most important source of primary biological aerosol particles in the model is bacteria, with emissions that are constant in time, representing inferred "background" emissions. In reality, bacteria emissions may exhibit seasonal or diurnal cycles, and may also be substantially higher in agricultural regions during periods of harvesting and other agricultural activity. Because these flights took place during September and October, harvesting of crops such as corn in the study area could plausibly have increased emissions of bacteria and other primary biological aerosol particles to as much as an order of 
magnitude more than typical background amounts (Lindemann et al., 1982; Lighthart, 1984; Lindemann and Upper, 1985).

\section{Implications for ice nucleation}

The WIBS-4A data indicate that 0.8 to $12 \mu \mathrm{m}$ FBAPs do sometimes reach altitudes and temperatures characteristic for heterogeneously nucleated ice. However, since only a small subset of all biological particles nucleates ice at these temperatures, how important may the measured concentrations of FBAPs be to ice formation under these conditions?

Ice crystal concentrations measured in deep frontal clouds during IDEAS were as high as $80 \mathrm{~L}^{-1}$, using a 2D-C probe with anti-shatter probe tips (Korolev et al., 2013). However, these frontal cases were likely impacted by ice nucleated through homogeneous freezing above, sedimenting into warmer temperatures below. In addition, under some conditions ice crystals may be formed by secondary processes (not involving aerosol particles; e.g., Hallett and Mossop, 1974). Cooper (1986) compiled data from several experiments, including some in the same region as this study, where ice was assumed to occur only from primary heterogeneous ice nucleation. He found that the number concentration of primary ice varied with temperature and could range by a factor of 100 even for similar temperature and cloud conditions. Nevertheless, $68 \%$ of the measurements from different parts of the world and in different cloud types were within about a factor of 6 for a given temperature between about 248 and $268 \mathrm{~K}$. The best-fit relationship was $\log 10\left(N_{\text {ice }}\right)=-2.35-$ $0.135 T_{\mathrm{C}}$, where $N_{\text {ice }}$ is in $\mathrm{L}^{-1}$ and $T_{\mathrm{C}}$ is temperature in ${ }^{\circ} \mathrm{C}$. Using the Cooper (1986) relationship, one would expect about $10 \mathrm{~L}^{-1}$ of primary ice at $248 \mathrm{~K}$, but much lower concentrations, $<0.1 \mathrm{~L}^{-1}$, at temperatures warmer than $263 \mathrm{~K}$. In the Colorado/Wyoming region, Twohy et al. (2010) examined ice concentrations in orographic wave clouds without upper-level seeding clouds, where ice concentrations were presumed to be associated with primary nucleation from upstream particles. At temperatures of 244-249 K, ice concentrations were typically $1-5 \mathrm{~L}^{-1}$, with a maximum of $17 \mathrm{~L}^{-1}$ in one case. These values are similar to those obtained with the Cooper (1986) parameterization for the same temperature range.

To compare these anticipated concentrations of primary ice formed through heterogeneous nucleation with potential INP concentrations in the IDEAS sampling region, INP number concentrations were estimated from WIBS-4A FBAP concentrations using Eq. (3) of Tobo et al. (2013) (T2013). This parameterization was based on INP concentrations measured using a continuous-flow diffusion chamber and FBAP concentrations measured by the UV-APS at the MEFO forested ground site in July-August 2011. The parameterization was shown to agree well with IDEAS field data for the MEFO location, as discussed in Sect. 4.1. Our analysis used the T2013 parameterization for the temperature range of the BEACHON-RoMBAS INP data set (243-263 K), plus an extrapolation to $7^{\circ}$ warmer to incorporate a broader range of FBAP data and temperatures where biological INPs are potentially important.

Predicted INP number concentrations as a function of ambient temperature are shown in colored circles (T2013) in Fig. 8a. Points where the parameterization was extrapolated to warmer temperatures are colored grey (T2013E in the figure) to indicate that they have greater uncertainty. Predicted INP concentrations are highly variable, as expected given the intra- and inter-flight variability of the FBAP concentrations. Even with the most liberal interpretation of which fluorescent particles are biological (magenta points), predicted INP concentrations are $<0.5 \mathrm{~L}^{-1}$. The Cooper (1986) primary ice concentrations (C1986) are plotted as blue hexagons for reference against the INP concentration predictions. Most of the predicted INP concentrations from fluorescent biological particles measured by the WIBS-4A are well below concentrations derived with the parameterization for primary ice in clouds. However, predicted INP concentrations for the highest FBAP concentrations at temperatures $\sim 268$ and $\sim 256 \mathrm{~K}$ are within a factor of 2 of typical ice concentrations, and those at $\sim 268 \mathrm{~K}$ sometimes exceed them.

Also shown for reference are predicted INP number concentrations from the parameterization D2010 of DeMott et al. (2010). Brown squares marked are within the temperature range of the original measurements and lighter colored squares are extrapolated to warmer temperatures. The parameterization D2010 was developed to relate INPs to the number concentration of all aerosol particles $>0.5 \mu \mathrm{m}$ diameter and includes data from the IDEAS sampling region. WIBS$4 \mathrm{~A}$ particle concentration between 0.8 and $12 \mu \mathrm{m}$ (both fluorescent and non-fluorescent) was substituted as a proxy for $>0.5 \mu \mathrm{m}$ particle concentration measured in DeMott et al. (2010). This size difference will underestimate concentrations by a factor that depends on the aerosol distribution, which could be expected to be at least a factor of 2 based on available data from past projects. This parameterization can be expected to reflect potential INP concentrations for the aerosol scenario present at the time of IDEAS measurements, whereas the Cooper (1986) parameterization reflects average conditions of observed ice concentrations over potentially different aerosol scenarios. All these parameterizations suggest variable contributions of fluorescent biological particle influences on total INPs and cloud ice concentrations at different altitudes and at different times.

The FBAP data presented here represent clear-air conditions, where transport from the boundary layer may not be very active. Under conditions of widespread uplift or strong convection that induce condensation of water vapor, higher concentrations of FBAPs might be lifted into the free troposphere, as suggested by Wright et al. (2014). To assess whether FBAPs measured in the boundary layer during IDEAS would be sufficient to account for typical ice 
(a)

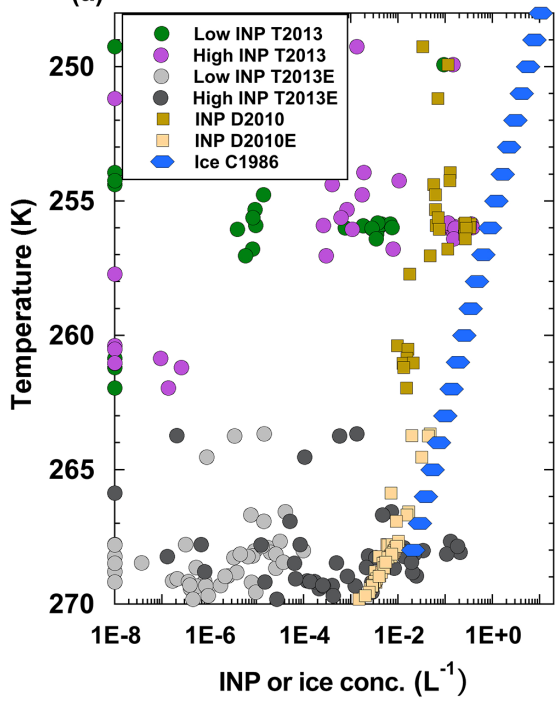

(b)

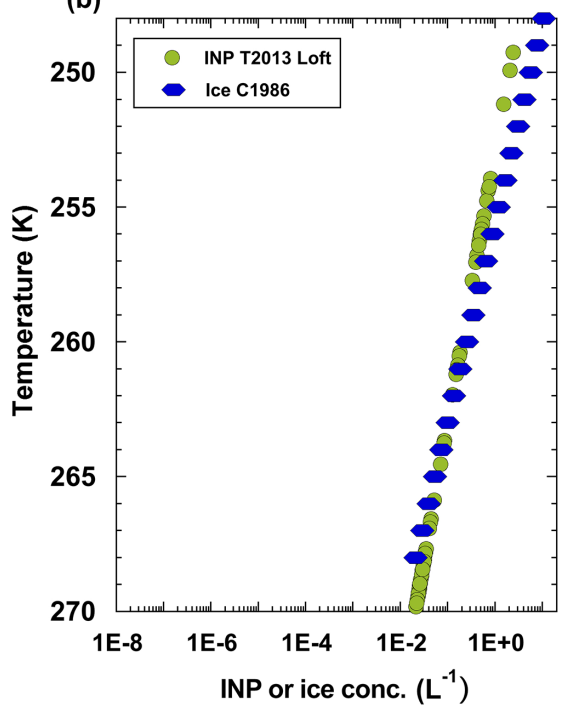

Figure 8. (a) Predicted INP concentration based on Tobo et al. (2013) (T2013) Eq. (3) and actual fluorescent biological particle concentrations $(0.8-12 \mu \mathrm{m})$ measured from the aircraft. Dark green and magenta circles are for low and high FBAP values, respectively, based on different definitions of which fluorescent particles are biological, as discussed in the text. Light and dark grey circles (T2013E) are extrapolated to warmer temperatures than the data used in T2013. Zeros are plotted as $1 \times 10^{-8}$ on the log scale. Brown squares are based on the global parameterization D2010 of DeMott et al. (2010) with WIBS-4A particle concentration between 0.8 and $12 \mu$ m substituted for particles $>0.5 \mu \mathrm{m}$. Lighter brown squares (D2010E) are extrapolations to warmer temperatures. Dark blue hexagons represent typical concentrations of primary ice at varying temperatures in clouds as measured and parameterized by Cooper (1986) (C1986). (b) Light green circles are a hypothetical prediction of INPs based on an FBAP concentration of $69 \mathrm{~L}^{-1}$ at $281 \mathrm{~K}$, assuming boundary-layer FBAPs were lifted to colder temperatures without losses in concentration. Dark blue hexagons are ice concentrations as in panel (a), based on C1986. Note that all data are presented here in ambient concentrations; however, as an intermediate step, FBAPs and INPs were converted to standard concentrations to use with the T2013 and D2010 parameterizations, as required for the equations developed in those papers. For adjusting air density, a best-fit relationship between temperature, $T(\mathrm{~K})$, and pressure, $P(\mathrm{mb})$, was developed for all flights: $P=1428-15.753 \times T+0.046654 \times T^{2}$.

concentrations in clouds under strong uplift conditions, we first averaged the high FBAP concentrations for the lowest, warmest aircraft samples (those with $T>279 \mathrm{~K}$ ). This mean concentration of about $69 \mathrm{~L}^{-1}$ (at $281 \mathrm{~K}$ ) was converted to INP number concentration using the Tobo et al. (2013) parameterization, assuming the parcel was lifted to higher altitudes (colder temperatures) without particle losses, but allowing for reduction in air density at higher altitudes. The predicted INP concentrations for this hypothetical case are shown as light green circles in Fig. $8 \mathrm{~b}$ and are within a factor of 2 to 3 of expected concentrations of primary ice based on Cooper (1986).

This approach is imperfect for a number of reasons. First, the parameterization of Tobo et al. (2013), originating at the MEFO forested ground site may not adequately represent the relationship between FBAPs and INPs in the free troposphere over grass and cropland, which represents most of the data used here. Garcia et al. (2012) found that significant numbers of INP, which they inferred to be dominated by biogenic (heat-labile) INPs, are present in the boundary layer in this region in the autumn season and that biological INPs are directly enhanced during harvesting operations. Also, the method used here detects only fluorescent parti- cles $0.8-12 \mu \mathrm{m}$, which may not include all biological INPs. While Mason et al. (2016) present evidence that the majority of continental INPs are in this size range, smaller biological particles have been detected in the free troposphere (Pratt and Prather, 2010). As discussed earlier, some submicron organic particles (or suspendible components of larger particles from arable soils, plants and sea spray), are known to nucleate ice (Vali, 1966; Pummer et al., 2012; Tobo et al., 2014; Wilson et al., 2015). These particles may accompany releases of FBAPs, but their atmospheric inputs are presently poorly quantified or validated. Simultaneous measurements of biological and ice-nucleating particles in the free troposphere would be very useful to help better understand these relationships.

Despite these limitations, this simple analysis suggests that primary fluorescent biological particles are likely important for ice formation in mixed-phase clouds under certain conditions, in particular when lifting is strong enough to bring them to sub-zero temperatures and to counteract natural losses through sedimentation. This may occur frequently in direct association with deep convection (Phillips et al., 2009; DeLeon-Rodriguez et al., 2013) where vertical velocities are strong. In areas impacted by long-range 
transport (Pratt et al., 2009) or orographic and frontal uplift, it may be more sporadic. For example, biological particles were found on only two of five flights targeting orographic clouds over the Rocky Mountains (Phillips et al., 2012). These same convective processes are expected to impact transport of mineral and other soil-dust, and dust and biological particles may be co-located (Pratt et al., 2009; Creamean et al., 2013). The greater abundance of mineral dust globally means that it will usually dominate the INP population at colder temperatures where it effectively nucleates ice and probably explains the dominance of mineral dust in cirrus clouds (Cziczo et al., 2013). Extensive laboratory data indicate, however, that biological particles remain the most likely source of INPs in the atmosphere for clouds with temperatures warmer than $\sim 258 \mathrm{~K}$. The variable and often low abundance of these INPs, however, may explain why clouds sometimes remain supercooled in the atmosphere, particularly at warmer temperatures (Kanitz et al., 2011; Komurcu et al., 2014).

\section{Conclusions and discussion}

The first vertical profiles of fluorescent biological aerosol particles in the free troposphere have been presented for the autumnal US Great Plains region during daytime hours. Concentrations of FBAPs between 0.8 and $12 \mu \mathrm{m}$ in diameter were $\sim 10-100 \mathrm{~L}^{-1}$ at temperatures warmer than $270 \mathrm{~K}$ in the atmospheric boundary layer. In the mid- to upper free troposphere at temperatures less than about $255 \mathrm{~K}$, FBAP concentrations were usually between 0 and $1 \mathrm{~L}^{-1}$. Variable and sometimes high concentrations of fluorescent biological particles were measured in the $\sim 2-5 \mathrm{~km}$ altitude range. In this region, this altitude range coincides with temperatures where mineral dusts are less active as INPs, so INPs of biological origin are likely critical to mixed-phase cloud formation. These data are consistent with and provide a bridge between prior measurements of biological particles near the surface, in the middle troposphere in mixed-phase clouds and in the upper troposphere in cirrus clouds.

Lower and upper bounds of FBAP concentrations were developed from the WIBS-4A data depending on fluorescent response, and translated to about an order of magnitude difference in number concentration for each sampling period. Further studies characterizing the WIBS-4A response to different types of biological particles in their atmospheric form are needed. In particular, preliminary analysis via scanning electron microscopy indicates that many irregular carbonaceous particle types, apparently plant-derived, were present in the IDEAS sampling region (James Anderson, personal communication, 2014). Laboratory evidence indicates that plant material such as cellulose and pectin can nucleate ice as efficiently as mineral dust (Hiranuma et al., 2015b; Möhler et al., 2016).
Filter measurements of ice-nucleating particles at two altitudes over the forested MEFO ground site showed that INP concentrations decrease with height, in accordance with the profiles of FBAPs from the WIBS-4A instrument. A simple, temperature-dependent relationship between FBAP concentration and ice-nucleating particles developed for that site was used to estimate INP concentrations for the data set as a whole in the temperature range of 243-270 K. Predicted INP concentrations measured in clear-air were sometimes sufficient to explain expected concentrations of primary ice crystals for clouds in the region but were often much lower. Several reasons were proposed for this. These include the possibility that the ground-based parameterization may not be representative of the wider data set, the potential for sub-micron biological particles to be INPs, and different atmospheric stabilities between the clear-air cases measured and cloudy conditions. If boundary-layer FBAP concentrations are hypothetically lifted to colder temperatures without losses, then predicted INP concentrations are quite close to expected ice crystal concentrations. In-cloud measurements of FBAPs and comparison with ice and droplet concentrations will be the focus of subsequent work.

A global chemistry-climate model was employed to simulate the emissions, transport, and removal from the atmosphere of three types of biological particles: bacteria, fungal spores, and pollen. The simulated particle concentrations declined with altitude in a manner generally consistent with observations. However, the model usually underpredicted the observed FBAP concentrations (typically by about an order of magnitude), which potentially could be due to errors in either modeled particle emissions, transport, or removal processes. A previous effort to model airborne FBAP observations by Perring et al. (2015) also found that the model consistently underpredicted observed concentrations. One likely factor in these discrepancies is that the model may be missing particle types, such as leaf litter or arable soils, which may contribute to FBAP concentrations. Another factor is that the model does not account for the potential for agricultural activities such as harvesting to produce substantially larger emissions of biological particles, an aspect that could be relevant in this field campaign, as most flights were largely over cropland during late September and October.

Because of the strong spatial and seasonal variability of biological particle emissions, the concentrations and profiles presented here are only representative of daytime hours in this region and season. However, the general decrease in FBAP with height and the sporadic incursions of high concentrations to the mid-troposphere are likely widespread phenomena. Since ice nucleation is such a strong function of temperature, the importance of these features to ice formation will vary with time and location, but in potentially complex ways. For example, the mid-troposphere is expected to be colder at night, in the wintertime, and at high latitudes. However, these are also conditions in which biological particle loadings may be lower, due to limited convection and 
fewer biological emissions. Conversely, temperatures may be relatively warm in the mid-troposphere during the day, in the summer and at lower latitudes, but these are also the conditions that usually support enhanced convection and increased biological emissions. In addition, increasing temperatures and changing biospheres due to climate change are expected to modify three factors that affect the importance of biological particles on ice formation: (1) emissions and types of primary biological particles, (2) atmospheric temperature profiles, and (3) convective intensity and frequency.

\section{Data availability}

Data used to create Fig. 1 were extracted from http://www. archive.arm.gov (SGP site Balloon-Borne Sounding System,
Micropulse Lidar and Multifilter Rotating Shadowband Radiometer data for 2007-2010; ARM data Archive Cente, $2015 \mathrm{a}, \mathrm{b}, \mathrm{c})$, and the seasonal extinction and temperature profiles are included in the first two files in the Supplement (S1 and S2). Flight track data (Fig. 2) are available in netcdf format at http://data.eol.ucar.edu/codiac/dss/id=378. 010 (UCAR/NCAR, 2015). FBAP and total particle concentrations, temperature, altitude, and interpolated model concentrations used in Figs. 3a and 4, 5, 6, 7, and 8 are provided in Supplement S3. INP filter data for Fig. 3b and c are available in S4. Grid-specific model output displayed in Fig. 7 (orange diamonds) is provided in S5-S9 (each for a different flight). All supplemental data are in tab-delimited column format with variable abbreviations and units given in the headers. 
Appendix A: CVI inlet sub-isokinetic transport efficiency

When sampling by aircraft through an inlet, the transport efficiency of aerosol particles includes the inlet aspiration efficiency, the inlet transmission efficiency, and the transmission of particles downstream through the tubing between the inlet and the sampling instrument. For the IDEAS measurements, the first two efficiencies were calculated using a complete computational fluid dynamics (CFD) model with commercial software. CFD has been used successfully with other airborne inlets (Moharreri et al., 2013) including CVIs (Laucks and Twohy, 1998; Kulkarni and Twohy, 2011). The tubing transmission efficiencies were calculated using a free IGOR Particle Loss Calculator (PLC) program created at the MaxPlanck Institute for Chemistry (von der Weiden et al., 2009). It is based on well-documented particle sampling and loss mechanisms found in the literature and has been validated for several complex tubing systems similar to what might be found in a complex aircraft-to-instrument transport environment.

\section{A1 Computational fluid dynamics modeling of CVI inlet aspiration and transmission efficiency}

A CFD model was used to calculate airflow and particle trajectories inside the airborne CVI inlet. As discussed in the main paper, the NCAR CVI was used without counterflow, as a sub-isokinetic inlet, to enhance the concentration of supermicron particles during clear-air sampling. The mesh representing the CVI geometry was generated using commercial GAMBIT software (version 2.4.6) for the CFD solver. For flow regions with large gradients in velocity and pressure magnitudes, a high-density mesh was implemented. To optimize the overall mesh density, both structured and unstructured mesh elements were used, and mesh density was further refined until a grid-independent CFD solution was obtained. Approximately 350000 cells were used to model the exterior free-stream domain, the CVI inlet geometry, which included the CVI tip, porous internal tube, and solid internal tubing up to where it meets the aircraft fuselage (Fig. A1). The exterior domain representing the free-stream flow around the inlet started $0.05 \mathrm{~m}$ upstream of the CVI inlet tip and extended 0.05 and $0.1 \mathrm{~m}$ in the vertical and horizontal, respectively.

Various types of boundary conditions were used to set up the model runs. The free-stream domain inlet was defined as a velocity-inlet based on the aircraft true airspeed, and the free-stream flow outlet was defined as a pressure outlet. A mass-flow boundary condition was used at the downstream end of the CVI, based on the known sample flow rate where it connects to the sample tubing inside the aircraft. The model simulations were calculated using the commercial CFD software FLUENT (ANSYS version 14.5), and the various CFD model parameters used in our study were as follows.

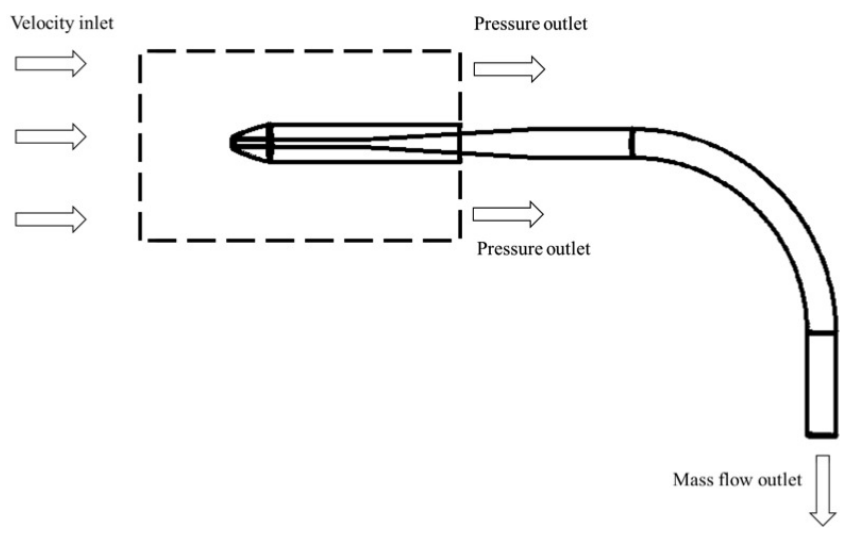

Figure A1. Model domain and boundary conditions for the computational fluid dynamic modeling of the CVI inlet, used as a subisokinetic inlet without counterflow.

We implemented the RNG k- $\varepsilon$ turbulence model to consider the effect of flow turbulence and used a Lagrangian discrete-phase model to simulate particle trajectories. Two sets of flight conditions were modeled, one representing relatively low-airspeed, low-altitude sampling conditions (free-stream velocity $128 \mathrm{~m} \mathrm{~s}^{-1}, 670 \mathrm{mb}$ ambient pressure) and one representing high-airspeed, high-altitude conditions (free-stream velocity $220 \mathrm{~m} \mathrm{~s}^{-1}, 300 \mathrm{mb}$ ambient pressure). The inlet aspiration efficiency of particles of different sizes was calculated by multiplying (a) the ratio of the inlet-plane area at the upstream domain through which particles are drawn into the CVI to the cross-sectional area of the CVI tip and (b) the ratio of the free-stream inlet flow velocity to the CVI tip sampling velocity. Given that the particle density and aerodynamic diameter of biological particles varies and can be less than or greater than $1.0 \mathrm{~g} \mathrm{~cm}^{-3}$ (Després et al., 2012; Hussein et al., 2013), particles were assumed to be unit-density spheres. Size-dependent transmission efficiencies inside the CVI were calculated by assuming that any particles whose trajectories contacted interior surfaces were not transmitted further.

\section{A2 Calculation of tubing transmission efficiency and net transport efficiency}

The PLC software (von der Weiden et al., 2009) calculates net particle transport through a series of tubing of different sizes, flow rates, and angles of curvature and inclination. Loss mechanisms include aerosol diffusion, sedimentation, and turbulent and inertial deposition. Thus, the program is useful for a variety of particle sizes and sampling conditions and for complex tubing arrangements that would be difficult to model using CFD. We utilized the PLC to calculate transport of unit-density particles from where the CVI inlet ends at the aircraft fuselage, through 7.8 and $4.8 \mathrm{~cm}$ inside diameter tubing to the WIBS-4A instrument and the ice nucleation filters. Because the default conditions of the PLC were set 
for ground-based conditions, air density, viscosity, and mean free path values were changed to reflect the actual CVI sampling conditions for the low-speed and high-speed cases.

Once aspiration efficiency, inlet efficiency, and downstream tubing efficiency were determined as a function of size for both airspeed conditions, they were multiplied together to produce a net transport efficiency for nine different particle size ranges corresponding to WIBS-4A channel diameters between 0.8 and $12 \mu \mathrm{m}$. Due to combined effects of sub-isokinetic enhancement and tubing losses, transport efficiency for different sizes ranged from about 1.5 to 8 at the lower airspeeds to 2 to 12 at the high airspeeds. A linear relationship between transport efficiency and airspeed was developed for each particle size. These were used to calculate corrected number concentrations at each WIBS-4A size channel, which were then integrated to obtain total FBAP concentrations for each $200 \mathrm{~s}$ interval presented in the main text. Uncertainty of the transport efficiency is discussed in Sect. 3.3 of the main text.

For the filter samples taken on the aircraft, the size distribution of the actual ice-nucleating particles was unknown. Therefore, we assumed that the number-mean INP size was approximately $2.5 \mu \mathrm{m}$ diameter, as estimated from ground-
Table A1. Summary of CFD model settings

\begin{tabular}{ll}
\hline Input summary & Settings \\
\hline Models & 3-D, Steady, RNG k- $\epsilon$ turbulence \\
& model, enhanced wall treatment \\
Pressure calculation & Standard \\
Momentum, turbulent & Second-order upwind \\
Energy & First-order upwind \\
Pressure-velocity coupling & SIMPLE \\
\hline
\end{tabular}

based BEACHON-RoMBAS data (Huffman et al., 2013) and from wider geographical measurements by Mason et al. (2016). The airborne filter INP concentrations were corrected by a single transport efficiency corresponding to the $2.5 \mu \mathrm{m}$ particle size at the corresponding airspeed. It should be noted, however, that INP sizes at higher altitudes may be smaller (e.g., DeMott et al., 2010). If the mean INP diameter were instead $1.0 \mu \mathrm{m}$, transport efficiencies would be about $50 \%$ of those at $2.5 \mu \mathrm{m}$, leading to an increase in the INP concentrations for filters $6 \mathrm{~A}$ and $6 \mathrm{~B}$ (Fig. 3b) by a factor of 2. 


\section{The Supplement related to this article is available online at doi:10.5194/acp-16-8205-2016-supplement.}

Author contributions. Cynthia H. Twohy oversaw the deployment and operation of instruments on the aircraft, led the data analysis, and prepared the manuscript, with input from all authors. Gavin R. McMeeking, Darin W. Toohey, and Christina S. McCluskey modified and installed equipment and helped with data analysis and interpretation. Paul J. DeMott, Thomas C. J. Hill, and Christina S. McCluskey provided INP filter samples and analysis and interpretation of them. Gourihar R. Kulkarni set up, ran, and compiled the computational fluid dynamics studies of the inlet. Susannah M. Burrows and Meryem Tanarhte set up, ran, and interpreted the global modeling studies. Durga N. Kafle calculated the seasonally averaged aerosol extinction profiles from the ARM lidar data.

Acknowledgements. This material was based on work supported by the US National Science Foundation under award numbers AGS1408028 (Cynthia H. Twohy), AGS-1358495 and AGS-1036028 (Paul J. DeMott and Thomas C. J. Hill), and AGS-1104642 (Darin W. Toohey). Gourihar R. Kulkarni and Susannah M. Burrows were supported by the US Department of Energy, Office of Science, BER program, at Pacific Northwest National Laboratory (PNNL). PNNL is operated by the US DOE by Battelle Memorial Institute under contract DE-AC05-76RL0 1830. James Anderson of Arizona State analyzed and provided preliminary interpretation of particle types via SEM. Greg Kok and Gary Granger of Droplet Measurement Technologies helped with modifications to the WIBS-4A. We thank Errol Korn, Gordon Maclean, and Kyle Holden for technical expertise, Jeff Stith for organizing the IDEAS field program, and the rest of the Research Aviation Facility staff for implementing it so skillfully. Frank Drewnick of the Max Planck Institute for Chemistry suggested changes to the Particle Loss Calculator program for airborne operations and Yiannis Proestos of The Cyprus Institute helped with model setup. We also acknowledge the US Department of Energy's Atmospheric Radiation Measurement (ARM) program and the scientists involved in providing the Southern Great Plains site MFRSR and SONDE data used in Fig. 1.

Edited by: A. Perring

\section{References}

Agresti, A. and Coull, B. A.: Approximate is better than "exact" for interval estimation of binomial proportions, Am. Stat., 52, 119126, doi:10.1080/00031305.1998.10480550, 1998.

ARM data Archive Cente: MPL data, sgpmplpolC1.b1.yyyymmddhhmmss.cdf, available at: http: //www.archive.arm.gov, last access: August 2015a.

ARM data Archive Cente: MFRSR data, sgpmfrsraod1michE4.C1.yyyymmddhhmmss.cdf, available at: http://www.archive.arm.gov, last access: August 2015b.
ARM data Archive Cente: SONDE data, sgpsondewnpnC1.b1.yyyymmddhhmmss.cdf, available at: http://www.archive.arm.gov, last access: September 2015c.

Burrows, S. M., Butler, T., Jöckel, P., Tost, H., Kerkweg, A., Pöschl, U., and Lawrence, M. G.: Bacteria in the global atmosphere - Part 2: Modeling of emissions and transport between different ecosystems, Atmos. Chem. Phys., 9, 9281-9297, doi:10.5194/acp-9-9281-2009, 2009a.

Burrows, S. M., Elbert, W., Lawrence, M. G., and Pöschl, U.: Bacteria in the global atmosphere - Part 1: Review and synthesis of literature data for different ecosystems, Atmos. Chem. Phys., 9, 9263-9280, doi:10.5194/acp-9-9263-2009, 2009 b.

Burrows, S. M., Rayner, P. J., Butler, T., and Lawrence, M. G.: Estimating bacteria emissions from inversion of atmospheric transport: sensitivity to modelled particle characteristics, Atmos. Chem. Phys., 13, 5473-5488, doi:10.5194/acp-13-5473-2013, 2013.

Chen, G., Ziemba, L. D., Chu, D. A., Thornhill, K. L., Schuster, G. L., Winstead, E. L., Diskin, G. S., Ferrare, R. A., Burton, S. P., Ismail, S., Kooi, S. A., Omar, A. H., Slusher, D. L., Kleb, M. M., Reid, J. S., Twohy, C. H., Zhang, H., and Anderson, B. E.: Observations of Saharan dust microphysical and optical properties from the Eastern Atlantic during NAMMA airborne field campaign, Atmos. Chem. Phys., 11, 723-740, doi:10.5194/acp11-723-2011, 2011

Cooper, W. A.: Ice initiation in natural clouds, in: Precipitation enhancement: A scientific challenge, Meteorological Monographs, American Meteorological Society, Boston, MA, USA, 1986.

Crawford, I., Robinson, N. H., Flynn, M. J., Foot, V. E., Gallagher, M. W., Huffman, J. A., Stanley, W. R., and Kaye, P. H.: Characterisation of bioaerosol emissions from a Colorado pine forest: results from the BEACHON-RoMBAS experiment, Atmos. Chem. Phys., 14, 8559-8578, doi:10.5194/acp-14-8559-2014, 2014.

Creamean, J. M., Suski, K. J., Rosenfeld, D., Cazorla, A., DeMott, P. J., Sullivan, R. C., White, A. B., Ralph, F. M., Minnis, P., Comstock, J. M., Tomlinson, J. M., and Prather, K. A.: Dust and Biological Aerosols from the Sahara and Asia Influence Precipitation in the Western US, Science, 339, 1572-1578, doi:10.1126/science.1227279, 2013.

Cziczo, D. J., Froyd, K. D., Hoose, C., Jensen, E. J., Diao, M., Zondlo, M. A., Smith, J. B., Twohy, C. H., and Murphy, D. M.: Clarifying the dominant sources and mechanisms of cirrus cloud formation, Science, 340, 1320-1324 doi:10.1126/science.1234145, 2013.

DeLeon-Rodriguez, N., Lathem, T. L., Rodriguez-R, L. M., Barazesh, J. M., Anderson, B. E., Beyersdorf, A. J., Ziemba, L. D., Bergin, M., Nenes, A., and Konstantinidis, K. T.: Microbiome of the upper troposphere: Species composition and prevalence, effects of tropical storms, and atmospheric implications, P. Natl. Acad. Sci., 110, 2575-2580, doi:10.1073/pnas.1212089110, 2013.

DeMott, P. J., Prenni, A. J., Liu, X., Kreidenweis, S. M., Petters, M. D., Twohy, C. H., Richardson, M. S., Eidhammer, T., and Rogers, D. C.: Predicting global atmospheric ice nuclei distributions and their impacts on climate, P. Natl. Acad. Sci. USA, 107, 11217 11222, doi:10.1073/pnas.0910818107, 2010.

Després, V. R., Alex Huffman, J., Burrows, S. M., Hoose, C., Safatov, A. S., Buryak, G., Fröhlich-Nowoisky, J., Elbert, W., An- 
dreae, M. O., Pöschl, U., and Jaenicke, R.: Primary biological aerosol particles in the atmosphere: a review, Tellus B, 64, 15598, doi:10.3402/tellusb.v64i0.15598, 2012.

Di-Giovanni, F., Kevan, P. G., and Nasr, M. E.: The variability in settling velocities of some pollen and spores, Grana, 34, 39-44, doi:10.1080/00173139509429031, 1995.

FDA, USGS, and NIST: Multi-Agency Radiological Laboratory Analytical Protocols Manual (MARLAP), FDA, USGS, NUREG-1576, EPA 402-B-04-001C, NTIS PB2004-105421, Alexandria, VA, USA, 2004.

Fisher, R. A.: On the interpretation of $\chi 2$ from contingency tables, and the calculation of P, J. R. Stat. Soc., 85, 87-94, doi:10.2307/2340521, 1922.

Fulton, J. D.: Microorganisms of the Upper Atmosphere: III. Relationship between Altitude and Micropopulation, Appl. Microbiol., 14, 237-240, 1966.

Gabey, A. M., Gallagher, M. W., Whitehead, J., Dorsey, J. R., Kaye, P. H., and Stanley, W. R.: Measurements and comparison of primary biological aerosol above and below a tropical forest canopy using a dual channel fluorescence spectrometer, Atmos. Chem. Phys., 10, 4453-4466, doi:10.5194/acp-10-4453-2010, 2010.

Gabey, A. M., Stanley, W. R., Gallagher, M. W., and Kaye, P. H.: The fluorescence properties of aerosol larger than $0.8 \mu \mathrm{m}$ in urban and tropical rainforest locations, Atmos. Chem. Phys., 11, 5491-5504, doi:10.5194/acp-11-5491-2011, 2011.

Garcia, E., Hill, T. C. J., Prenni, A. J., DeMott, P. J., Franc, G. D., and Kreidenweis, S. M.: Biogenic ice nuclei in boundary layer air over two U.S. High Plains agricultural regions, J. Geophys. Res.-Atmos., 117, D18209, doi:10.1029/2012JD018343, 2012.

Hallett, J. and Mossop, S. C.: Production of secondary ice particles during the riming process, Nature, 249, 26-28, 1974.

Harrison, L., Michalsky, J., and Berndt, J.: Automated multifilter rotating shadow-band radiometer: an instrument for optical depth and radiation measurements, Appl. Optics, 33, 5118-5125, doi:10.1364/AO.33.005118, 1994.

Heald, C. L. and Spracklen, D. V.: Atmospheric budget of primary biological aerosol particles from fungal spores, Geophys. Res. Lett., 36, L09806, doi:10.1029/2009GL037493, 2009.

Hill, T. C. J., Moffett, B. F., DeMott, P. J., Georgakopoulos, D. G., Stump, W. L., and Franc, G. D.: Measurement of ice nucleation-active bacteria on plants and in precipitation by quantitative PCR, Appl. Environ. Microb., 80, 1256-1267, doi:10.1128/AEM.02967-13, 2014.

Hiranuma, N., Augustin-Bauditz, S., Bingemer, H., Budke, C., Curtius, J., Danielczok, A., Diehl, K., Dreischmeier, K., Ebert, M., Frank, F., Hoffmann, N., Kandler, K., Kiselev, A., Koop, T., Leisner, T., Möhler, O., Nillius, B., Peckhaus, A., Rose, D., Weinbruch, S., Wex, H., Boose, Y., DeMott, P. J., Hader, J. D., Hill, T. C. J., Kanji, Z. A., Kulkarni, G., Levin, E. J. T., McCluskey, C. S., Murakami, M., Murray, B. J., Niedermeier, D., Petters, M. D., O'Sullivan, D., Saito, A., Schill, G. P., Tajiri, T., Tolbert, M. A., Welti, A., Whale, T. F., Wright, T. P., and Yamashita, K.: A comprehensive laboratory study on the immersion freezing behavior of illite NX particles: a comparison of 17 ice nucleation measurement techniques, Atmos. Chem. Phys., 15, 2489-2518, doi:10.5194/acp-15-2489-2015, 2015a.

Hiranuma, N., Möhler, O., Yamashita, K., Tajiri, T., Saito, A., Kiselev, A., Hoffmann, N., Hoose, C., Jantsch, E., Koop, T., and Murakami, M.: Ice nucleation by cellulose and its potential con- tribution to ice formation in clouds, Nat. Geosci., 8, 273-277, doi:10.1038/ngeo2374, 2015b.

Holdridge, D., Prell, J., Ritsche, M., and Coulter, R. L.: BalloonBorne Sounding System Handbook, Atmospheric Radiation Measurement Climate Research Facility, Dept. of Energy, ARM TR-029, 27, 2011.

Hoose, C., Kristjánsson, J. E., and Burrows, S. M.: How important is biological ice nucleation in clouds on a global scale?, Environ. Res. Lett., 5, 024009, doi:10.1088/1748-9326/5/2/024009, 2010.

Huffman, J. A., Prenni, A. J., DeMott, P. J., Pöhlker, C., Mason, R. H., Robinson, N. H., Fröhlich-Nowoisky, J., Tobo, Y., Després, V. R., Garcia, E., Gochis, D. J., Harris, E., Müller-Germann, I., Ruzene, C., Schmer, B., Sinha, B., Day, D. A., Andreae, M. O., Jimenez, J. L., Gallagher, M., Kreidenweis, S. M., Bertram, A. K., and Pöschl, U.: High concentrations of biological aerosol particles and ice nuclei during and after rain, Atmos. Chem. Phys., 13, 6151-6164, doi:10.5194/acp-13-6151-2013, 2013.

Hussein, T., Norros, V., Hakala, J., Petäjä, T., Aalto, P. P., Rannik, Ü., Vesala, T., and Ovaskainen, O.: Species traits and inertial deposition of fungal spores, J. Aerosol Sci., 61, 81-98, doi:10.1016/j.jaerosci.2013.03.004, 2013.

Jacobson, M. Z. and Streets, D. G.: Influence of future anthropogenic emissions on climate, natural emissions, and air quality, J. Geophys. Res.-Atmos., 114, D08118, doi:10.1029/2008JD011476, 2009.

Jaenicke, R.: Abundance of Cellular Material and Proteins in the Atmosphere, Science, 308, 73-73, doi:10.1126/science.1106335, 2005.

Jeuken, A. B. M., Siegmund, P. C., Heijboer, L. C., Feichter, J., and Bengtsson, L.: On the potential of assimilating meteorological analyses in a global climate model for the purpose of model validation, J. Geophys. Res.-Atmos., 101, 16939-16950, doi:10.1029/96JD01218, 1996.

Jöckel, P., Sander, R., Kerkweg, A., Tost, H., and Lelieveld, J.: Technical Note: The Modular Earth Submodel System (MESSy) - a new approach towards Earth System Modeling, Atmos. Chem. Phys., 5, 433-444, doi:10.5194/acp-5-433-2005, 2005.

Jöckel, P., Tost, H., Pozzer, A., Brühl, C., Buchholz, J., Ganzeveld, L., Hoor, P., Kerkweg, A., Lawrence, M. G., Sander, R., Steil, B., Stiller, G., Tanarhte, M., Taraborrelli, D., van Aardenne, J., and Lelieveld, J.: The atmospheric chemistry general circulation model ECHAM5/MESSy1: consistent simulation of ozone from the surface to the mesosphere, Atmos. Chem. Phys., 6, 50675104, doi:10.5194/acp-6-5067-2006, 2006.

Kafle, D. N. and Coulter, R. L.: Micropulse lidar-derived aerosol optical depth climatology at ARM sites worldwide, J. Geophys. Res., 118, 7293-7308, doi:10.1002/jgrd.50536, 2013.

Kanitz, T., Seifert, P., Ansmann, A., Engelmann, R., Althausen, D., Casiccia, C., and Rohwer, E. G.: Contrasting the impact of aerosols at northern and southern midlatitudes on heterogeneous ice formation, Geophys. Res. Lett., 38, L17802, doi:10.1029/2011GL048532, 2011.

Kaye, P., Stanley, W. R., Hirst, E., Foot, E. V., Baxter, K. L., and Barrington, S. J.: Single particle multichannel bioaerosol fluorescence sensor, Opt. Express, 13, 3583-3593, doi:10.1364/OPEX.13.003583, 2005.

Kerkweg, A., Buchholz, J., Ganzeveld, L., Pozzer, A., Tost, H., and Jöckel, P.: Technical Note: An implementation of the dry removal processes DRY DEPosition and SEDImentation in the Modu- 
lar Earth Submodel System (MESSy), Atmos. Chem. Phys., 6, 4617-4632, doi:10.5194/acp-6-4617-2006, 2006.

King, W. D.: Air flow and particle trajectories around aircraft fuselages. I: Theory, J. Atmos. Ocean. Tech., 1, 5-13, doi:10.1175/1520-0426(1984)001<0005:AFAPTA>2.0.CO;2, 1984.

Komurcu, M., Storelvmo, T., Tan, I., Lohmann, U., Yun, Y., Penner, J. E., Wang, Y., Liu, X., and Takemura, T.: Intercomparison of the cloud water phase among global climate models, J. Geophys. Res.-Atmos., 119, 3372-3400, doi:10.1002/2013JD021119, 2014.

Korolev, A., Emery, E., and Creelman, K.: Modification and Tests of Particle Probe Tips to Mitigate Effects of Ice Shattering, J. Atmos. Ocean. Tech., 30, 690-708, doi:10.1175/jtech-d-1200142.1, 2013.

Krämer, M. and Afchine, A.: Sampling characteristics of inlets operated at low U/U0 ratios: new insights from computational fluid dynamics (CFX) modeling, J. Aerosol Sci., 35, 683-694, doi:10.1016/j.jaerosci.2003.11.011, 2004.

Kulkarni, G. and Twohy, C.: Computational fluid dynamics studies to understand ice crystal and liquid droplet breakup within an airborne counterflow virtual impactor, Thirtieth Annual Conference, American Association for Aerosol Research, 3-7 October 2011, Orlando, FL, USA, 2011.

Kumar, P., Sokolik, I. N., and Nenes, A.: Measurements of cloud condensation nuclei activity and droplet activation kinetics of fresh unprocessed regional dust samples and minerals, Atmos. Chem. Phys., 11, 3527-3541, doi:10.5194/acp-11-3527-2011, 2011.

Laucks, M. L. and Twohy, C. H.: Size-dependent collection efficiency of an airborne counterflow virtual impactor, Aerosol. Sci. Tech., 28, 40-61, 1998.

Lighthart, B.: Microbial aerosols: estimated contribution of combine harvesting to an airshed, Appl. Environ. Microb., 47, 430432, 1984.

Lindemann, J. and Upper, C. D.: Aerial Dispersal of Epiphytic Bacteria over Bean Plants, Appl. Environ. Microb., 50, 1229-1232, 1985.

Lindemann, J., Constantinidou, H. A., Barchet, W. R., and Upper, C. D.: Plants as sources of airborne bacteria, including ice nucleation-active bacteria, Appl. Environ. Microb., 44, 10591063, 1982.

Mason, R. H., Si, M., Chou, C., Irish, V. E., Dickie, R., Elizondo, P., Wong, R., Brintnell, M., Elsasser, M., Lassar, W. M., Pierce, K. M., Leaitch, W. R., MacDonald, A. M., Platt, A., Toom-Sauntry, D., Sarda-Estève, R., Schiller, C. L., Suski, K. J., Hill, T. C. J., Abbatt, J. P. D., Huffman, J. A., DeMott, P. J., and Bertram, A. K.: Size-resolved measurements of ice-nucleating particles at six locations in North America and one in Europe, Atmos. Chem. Phys., 16, 1637-1651, doi:10.5194/acp-16-1637-2016, 2016.

Mishra, M. K., Rajeev, K., Thampi, B. V., and Nair, A. K. M.: Annual variations of the altitude distribution of aerosols and effect of long-range transport over the southwest Indian Peninsula, Atmos. Environ., 81, 51-59, doi:10.1016/j.atmosenv.2013.08.066, 2013.

Moharreri, A., Craig, L., Rogers, D. C., and Dhaniyala, S.: A New Aircraft Inlet for Sampling Interstitial Aerosol: Design Methodology, Modeling, and Wind Tunnel Tests, Aerosol Sci. Tech., 47, 885-894, doi:10.1080/02786826.2013.800186, 2013.
Möhler, O., DeMott, P. J., Vali, G., and Levin, Z.: Microbiology and atmospheric processes: the role of biological particles in cloud physics, Biogeosciences, 4, 1059-1071, doi:10.5194/bg-4-10592007, 2007.

Möhler, O., Hiranuma, N., Ullrich, R., and Hoose, C.: The potential contribution of plant materials to the ice nucleation activity of vegetated soil dust, 96th Annual Meeting, 10-14 January 2016, New Orleans, LA, USA, 2016.

Murray, B. J., O'Sullivan, D., Atkinson, J. D., and Webb, M. E.: Ice nucleation by particles immersed in supercooled cloud droplets, Chem. Soc. Rev., 41, 6519-6554, doi:10.1039/C2CS35200A, 2012.

Niklas, K.: The aerodynamics of wind pollination, Bot. Rev., 51, 328-386, doi:10.1007/BF02861079, 1985.

Nilsson, E. D., Rannik, Ü., Kumala, M., Buzorius, G., and Dowd, C. D.: Effects of continental boundary layer evolution, convection, turbulence and entrainment on aerosol formation, Tellus B, 53, 441-461, doi:10.1034/j.1600-0889.2001.530409.x, 2001.

Ortega, J., Turnipseed, A., Guenther, A. B., Karl, T. G., Day, D. A., Gochis, D., Huffman, J. A., Prenni, A. J., Levin, E. J. T., Kreidenweis, S. M., DeMott, P. J., Tobo, Y., Patton, E. G., Hodzic, A., Cui, Y. Y., Harley, P. C., Hornbrook, R. S., Apel, E. C., Monson, R. K., Eller, A. S. D., Greenberg, J. P., Barth, M. C., CampuzanoJost, P., Palm, B. B., Jimenez, J. L., Aiken, A. C., Dubey, M. K., Geron, C., Offenberg, J., Ryan, M. G., Fornwalt, P. J., Pryor, S. C., Keutsch, F. N., DiGangi, J. P., Chan, A. W. H., Goldstein, A. H., Wolfe, G. M., Kim, S., Kaser, L., Schnitzhofer, R., Hansel, A., Cantrell, C. A., Mauldin, R. L., and Smith, J. N.: Overview of the Manitou Experimental Forest Observatory: site description and selected science results from 2008 to 2013, Atmos. Chem. Phys., 14, 6345-6367, doi:10.5194/acp-14-6345-2014, 2014.

O'Sullivan, D., Murray, B. J., Ross, J. F., Whale, T. F., Price, H. C., Atkinson, J. D., Umo, N. S., and Webb, M. E.: The relevance of nanoscale biological fragments for ice nucleation in clouds, Scientific Reports, 5, 8082, doi:10.1038/srep08082, 2015.

Perring, A. E., Schwarz, J. P., Baumgardner, D., Hernandez, M. T., Spracklen, D. V., Heald, C. L., Gao, R. S., Kok, G., McMeeking, G. R., McQuaid, J. B., and Fahey, D. W.: Airborne observations of regional variation in fluorescent aerosol across the United States, J. Geophys. Res.-Atmos., 120, 1153-1170, doi:10.1002/2014JD022495, 2015.

Phillips, V. T. J., Andronache, C., Christner, B., Morris, C. E., Sands, D. C., Bansemer, A., Lauer, A., McNaughton, C., and Seman, C.: Potential impacts from biological aerosols on ensembles of continental clouds simulated numerically, Biogeosciences, 6 , 987-1014, doi:10.5194/bg-6-987-2009, 2009.

Phillips, V. T. J., Demott, P. J., Andronache, C., Pratt, K. A., Prather, K. A., Subramanian, R., and Twohy, C.: Improvements to an empirical parameterization of heterogeneous ice nucleation and Its comparison with observations, J. Atmos. Sci., 70, 378-409, doi:10.1175/JAS-D-12-080.1, 2012.

Pöhlker, C., Huffman, J. A., and Pöschl, U.: Autofluorescence of atmospheric bioaerosols - fluorescent biomolecules and potential interferences, Atmos. Meas. Tech., 5, 37-71, doi:10.5194/amt-537-2012, 2012.

Pozzer, A., de Meij, A., Pringle, K. J., Tost, H., Doering, U. M., van Aardenne, J., and Lelieveld, J.: Distributions and regional budgets of aerosols and their precursors simulated with the EMAC 
chemistry-climate model, Atmos. Chem. Phys., 12, 961-987, doi:10.5194/acp-12-961-2012, 2012.

Pratt, K. A. and Prather, K. A.: Aircraft measurements of vertical profiles of aerosol mixing states, J. Geophys. Res.-Atmos., 115, D11305, doi:10.1029/2009JD013150, 2010.

Pratt, K. A., DeMott, P. J., French, J. R., Wang, Z., Westphal, D. L., Heymsfield, A. J., Twohy, C. H., Prenni, A. J., and Prather, K. A.: In situ detection of biological particles in cloud ice-crystals, Nat. Geosci., 2, 397-400, doi:10.1038/Ngeo521, 2009.

Prenni, A. J., Tobo, Y., Garcia, E., DeMott, P. J., Huffman, J. A., McCluskey, C. S., Kreidenweis, S. M., Prenni, J. E., Pöhlker, C., and Pöschl, U.: The impact of rain on ice nuclei populations at a forested site in Colorado, Geophys. Res. Lett., 40, 227-231, doi:10.1029/2012GL053953, 2013.

Pummer, B. G., Bauer, H., Bernardi, J., Bleicher, S., and Grothe, H.: Suspendable macromolecules are responsible for ice nucleation activity of birch and conifer pollen, Atmos. Chem. Phys., 12, 2541-2550, doi:10.5194/acp-12-2541-2012, 2012.

Schneider, J., Freutel, F., Zorn, S. R., Chen, Q., Farmer, D. K., Jimenez, J. L., Martin, S. T., Artaxo, P., Wiedensohler, A., and Borrmann, S.: Mass-spectrometric identification of primary biological particle markers and application to pristine submicron aerosol measurements in Amazonia, Atmos. Chem. Phys., 11, 11415-11429, doi:10.5194/acp-11-11415-2011, 2011.

Schnell, R. C. and Vali, G.: World-wide source of leaf-derived freezing nuclei, Nature, 246, 212-213, 1973.

Schumacher, C. J., Pöhlker, C., Aalto, P., Hiltunen, V., Petäjä, T., Kulmala, M., Pöschl, U., and Huffman, J. A.: Seasonal cycles of fluorescent biological aerosol particles in boreal and semiarid forests of Finland and Colorado, Atmos. Chem. Phys., 13, 11987-12001, doi:10.5194/acp-13-11987-2013, 2013.

Shaffer, B. T. and Lighthart, B.: Survey of culturable airborne bacteria at four diverse locations in Oregon: urban, rural, forest, and coastal., Microb. Ecol., 34, 167-177, doi:10.1007/s002489900046, 1997.

Spurny, K. R. and Lodge, J. P. J.: Collection efficiency tables for membrane filters used in the sampling and analysis of aerosols and hydrosols, National Center for Atmospheric Research, Boulder, CO, USA, 1972.

Tobo, Y., Prenni, A. J., DeMott, P. J., Huffman, J. A., McCluskey, C. S., Tian, G., Pöhlker, C., Pöschl, U., and Kreidenweis, S. M.: Biological aerosol particles as a key determinant of ice nuclei populations in a forest ecosystem, J. Geophys. Res.-Atmos., 118, 10100-110110, doi:10.1002/jgrd.50801, 2013.

Tobo, Y., DeMott, P. J., Hill, T. C. J., Prenni, A. J., SwobodaColberg, N. G., Franc, G. D., and Kreidenweis, S. M.: Organic matter matters for ice nuclei of agricultural soil origin, Atmos. Chem. Phys., 14, 8521-8531, doi:10.5194/acp-14-8521-2014, 2014.

Tong, Y.: Diurnal distribution of total and culturable atmospheric bacteria at a rural site, Aerosol Sci. Tech., 30, 246-254, doi:10.1080/027868299304822, 1999.

Tong, Y. and Lighthart, B.: The annual bacterial particle concentration and size distribution in the ambient atmosphere in a rural area of the Willamette Valley, Aerosol Sci. Tech., 32, 393-403, doi:10.1080/027868200303533, 2000.
Toprak, E. and Schnaiter, M.: Fluorescent biological aerosol particles measured with the Waveband Integrated Bioaerosol Sensor WIBS-4: laboratory tests combined with a one year field study, Atmos. Chem. Phys., 13, 225-243, doi:10.5194/acp-13225-2013, 2013.

Tost, H., Jöckel, P., Kerkweg, A., Sander, R., and Lelieveld, J.: Technical note: A new comprehensive SCAVenging submodel for global atmospheric chemistry modelling, Atmos. Chem. Phys., 6, 565-574, doi:10.5194/acp-6-565-2006, 2006.

Twohy, C. H.: Measurements of Saharan dust in convective clouds over the tropical eastern Atlantic Ocean, J. Atmos. Sci., 72, 7581, doi:10.1175/JAS-D-14-0133.1, 2014.

Twohy, C. H., Kreidenweis, S. M., Eidhammer, T., Browell, E. V., Heymsfield, A. J., Bansemer, A. R., Anderson, B. E., Chen, G., Ismail, S., DeMott, P. J., and Van den Heever, S. C.: Saharan dust particles nucleate droplets in eastern Atlantic clouds, Geophys. Res. Lett., 36, L01807, doi:10.1029/2008g1035846, 2009.

Twohy, C. H., DeMott, P. J., Pratt, K. A., Subramanian, R., Kok, G. L., Murphy, S. M., Lersch, T., Heymsfield, A. J., Wang, Z. E., Prather, K. A., and Seinfeld, J. H.: Relationships of biomassburning aerosols to ice in orographic wave clouds, J. Atmos. Sci., 67, 2437-2450, doi:10.1175/2010jas3310.1, 2010.

UCAR/NCAR - Earth Observing Laboratory: Low Rate (LRT 1 sps) Navigation, State Parameter, and Microphysics FlightLevel Data, available at: http://data.eol.ucar.edu/codiac/dss/id= 378.010, last access: March 2015.

Vali, G.: Sizes of Atmospheric Ice Nuclei, Nature, 212, 384-385, 1966.

Vali, G.: Quantitative evaluation of experimental results on the heterogeneous freezing nucleation of supercooled liquids, J. Atmos. Sci., 28, 402-409, 1971.

von der Weiden, S.-L., Drewnick, F., and Borrmann, S.: Particle Loss Calculator - a new software tool for the assessment of the performance of aerosol inlet systems, Atmos. Meas. Tech., 2, 479-494, doi:10.5194/amt-2-479-2009, 2009.

Wang, C.-C., Fang, G.-C., and Lee, L.: Bioaerosols study in central Taiwan during summer season, Toxicol. Ind. Health, 23, 133139, 2007.

Weinzierl, B., Petzold, A., Esselborn, M., Wirth, M., Rasp, K., Kandler, K., Schütz, L., Koepke, P., and Fiebig, M.: Airborne measurements of dust layer properties, particle size distribution and mixing state of Saharan dust during SAMUM 2006, Tellus B, 61, 96-117, doi:10.1111/j.1600-0889.2008.00392.x, 2009.

Wilson, T. W., Ladino, L. A., Alpert, P. A., Breckels, M. N., Brooks, I. M., Browse, J., Burrows, S. M., Carslaw, K. S., Huffman, J. A., Judd, C., Kilthau, W. P., Mason, R. H., McFiggans, G., Miller, L. A., Najera, J. J., Polishchuk, E., Rae, S., Schiller, C. L., Si, M., Temprado, J. V., Whale, T. F., Wong, J. P. S., Wurl, O., Yakobi-Hancock, J. D., Abbatt, J. P. D., Aller, J. Y., Bertram, A. K., Knopf, D. A., and Murray, B. J.: A marine biogenic source of atmospheric ice-nucleating particles, Nature, 525, 234-238, doi:10.1038/nature14986, 2015.

Wright, T. P., Hader, J. D., McMeeking, G. R., and Petters, M. D.: High relative humidity as a trigger for widespread release of ice nuclei, Aerosol Sci. Tech., 48, i-v, doi:10.1080/02786826.2014.968244, 2014. 